\title{
The Role of Nuclear Energy in Establishing Sustainable Energy Paths
}

J.J.C. Bruggink, ECN

B.C.C. van der Zwaan, IVM
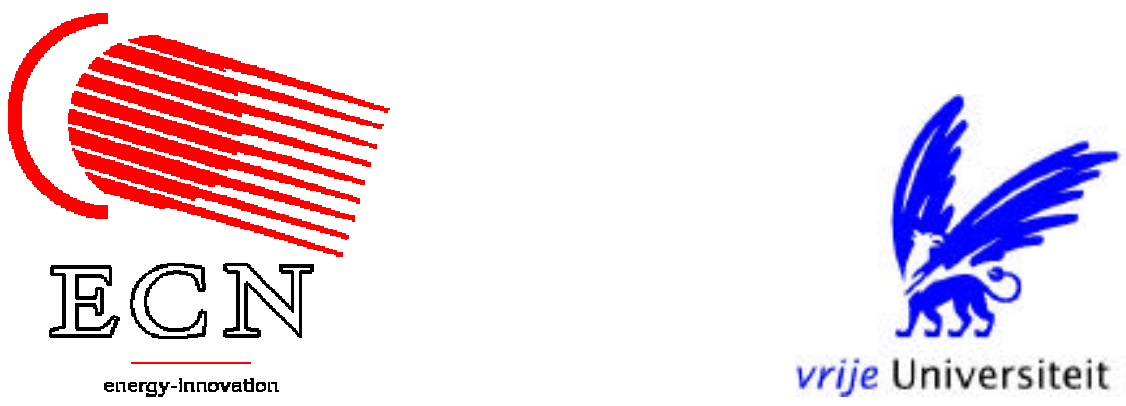

vrije Universiteit amsterdam / IVM 


\title{
Acknowledgement
}

For the preparation of this document on the role of nuclear energy in establishing sustainable energy paths, the authors have received useful input and help from many people, with often diverging opinions on the subject matter. They particularly acknowledge the valuable feedback and comments provided on an earlier version of this report by Ger Küpers, Paul Lako, Marjolein Quené, Frans Saris, Wim Turkenburg, Harmen Verbruggen and André Versteegh. The authors, however, are entirely responsible for the contents of the report, as well as for all remaining errors.

The analysis for this report has been carried out within project number 7.7380. With reference to this report number additional copies can be ordered (see the inside of the cover of this report).

\begin{abstract}
This study juxtaposes the major facts and arguments about nuclear energy and its potential role in establishing sustainable energy paths. The notion of sustainability has a strong normative character and can be interpreted in a variety of ways. Therefore, also the sustainability of energy supply technologies possesses a normative nature. This paper analyses what the major dimensions are that ought to be addressed when nuclear energy technology is compared, in sustainability terms, with its fossil-fuelled and renewable counterparts. It is assessed to what extent energy supply portfolios including nuclear energy are more, or less, sustainable in comparison to those that exclude this technology. It is indicated what this inventory of collected facts and opinions means for both policy and research regarding nuclear energy in the case of the Netherlands.
\end{abstract}




\section{CONTENTS}

MANAGEMENT SAMENVATTING

S.1 Inleiding

S.2 De risico's van kernenergie 5

$\begin{array}{lll}\text { S.3 } & \text { Generieke vergelijking met andere energieopties } & 7\end{array}$

S.4 De rol van kernenergie voor een mondiaal duurzaam energiepad 9

1. INTRODUCTION 11

$\begin{array}{lll}1.1 & \text { Purpose and scope of study } & 11\end{array}$

$\begin{array}{ll}1.2 \text { Concept of sustainable energy paths } & 11\end{array}$

$\begin{array}{ll}1.3 & \text { Normative aspects of sustainability } \\ 11\end{array}$

$\begin{array}{lll}1.4 & \text { Sustainable energy paths and renewable energy sources } & 12\end{array}$

$\begin{array}{ll}1.5 & \text { Role of nuclear energy in sustainable energy paths } \\ \end{array}$

$\begin{array}{ll}1.6 & \text { Key sources of background material } \\ \end{array}$

2. NUCLEAR ENERGY'S RISKS 14

$\begin{array}{lll}2.1 & \text { Radioactive waste } & 14\end{array}$

2.1.1 Overview of the nuclear fuel cycle 14

$\begin{array}{ll}\text { 2.1.2 Radioactive emissions } & 16\end{array}$

$\begin{array}{ll}2.1 .3 & \text { Spent fuel } \\ & 16\end{array}$

2.2 Reactor accidents 20

2.2.1 Incident probability and control of consequences 20

$\begin{array}{ll}\text { 2.2.2 Safety improvements since the 1980s } & 21\end{array}$

$\begin{array}{lll}2.3 & \text { Nuclear proliferation } & 23\end{array}$

2.3.1 Sources of proliferation 23

2.3.2 The issue of reprocessing 23

$\begin{array}{ll}\text { 2.3.3 Innovations to avoid proliferation } & 24\end{array}$

$\begin{array}{ll}\text { 2.3.4 Institutional issues } & 24\end{array}$

2.4 Economic competitiveness and market performance 25

$\begin{array}{lll}2.4 .1 & \text { Current situation } & 25\end{array}$

2.4.2 Cost structure, liberalisation and interest rates 26

$\begin{array}{ll}\text { 2.4.3 Market regulation and externalities } & 27\end{array}$

$\begin{array}{lll}2.5 & \text { Energy resources, reserves and prices } & 28\end{array}$

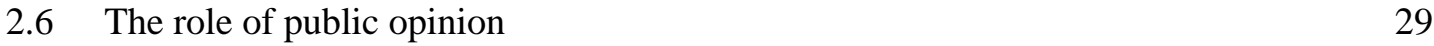

$\begin{array}{lll}2.6 .1 & \text { National nuclear energy programmes } & 29\end{array}$

2.6.2 The critical West, apathetic East and awakening South 30

3. GENERIC RISK COMPARISON BETWEEN NUCLEAR AND COMPETING ENERGY RESOURCES 31

$\begin{array}{lll}\text { 3.1 } & \text { Risk management along sustainable energy paths } & 31\end{array}$

3.1.1 The importance of risk management for sustainability strategies 31

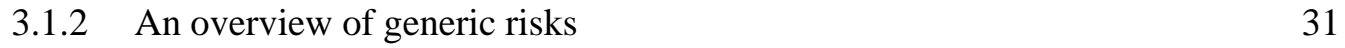

3.2 Economic risks 31

$\begin{array}{lll}3.2 .1 & \text { Market performance } & 31\end{array}$

$\begin{array}{lll}3.2 .2 & \text { Energy supply security } & 32\end{array}$

$\begin{array}{lll}3.2 .3 & \text { Resource availability } & 32\end{array}$

$\begin{array}{lll}3.3 & \text { Environmental risks } & 33\end{array}$

$\begin{array}{lll}\text { 3.3.1 } & \text { Global climate change } & 33\end{array}$

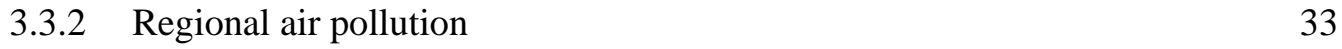

$\begin{array}{lll}3.3 .3 & \text { Local air pollution } & 34\end{array}$

$\begin{array}{lll}3.3 .4 & \text { Solid wastes } & 34\end{array}$

$\begin{array}{ll}\text { 3.3.5 Land use impacts } & 34\end{array}$

$\begin{array}{lll}\text { 3.3.6 Severe accidents } & 34\end{array}$

$\begin{array}{lll}3.4 & \text { Social risks } & 35\end{array}$

3.4.1 Technological infrastructure $\quad 35$

3.4.2 Public opinion $\quad 35$ 
4. CONCLUSIONS 37

4.1 The nuclear role in global sustainable energy paths 37

4.1.1 Important nuclear potential for transition period up to 2020

4.1.2 Determinants of nuclear competitiveness after $2020 \quad 37$

4.1.3 Nuclear energy as a global hedging option 38

4.2 Scenarios for nuclear energy policy in the Netherlands 39

$\begin{array}{lll}\text { 4.2.1 The scenario of bottom-line retreat } & 39\end{array}$

$\begin{array}{lll}\text { 4.2.2 The scenario of cautious standstill } & 39\end{array}$

4.2.3 The scenario of active involvement $\quad 40$

REFERENCES 41 


\section{MANAGEMENT SAMENVATTING}

\section{S.1 Inleiding}

\section{Doelstelling en reikwijdte studie}

Doelstelling van deze studie is het vastleggen en interpreteren van feiten en meningen, die een belangrijke rol spelen bij het beoordelen van de mogelijke rol van kernenergie voor het bereiken van een duurzame energievoorziening. Dit vereist een vergelijking met andere energietechnologieën op basis van verschillende dimensies van duurzaamheid. De studie heeft een samenvattend karakter, in die zin dat er geen nieuw feitenmateriaal wordt aangedragen. Wel worden de implicaties van feiten en meningen voor beleid en onderzoek in Nederland aangegeven.

\section{De definitie van een duurzame energievoorziening}

De duurzaamheid van de energievoorziening moet worden gezien als een normatief en dynamisch concept, dat bepaald wordt door sociale, economische en milieutechnische karakteristieken, die veranderen in de tijd en van land tot land verschillend gewogen worden. Deze karakteristieken zijn niet op objectieve wijze en op basis van empirische gegevens onder één noemer te brengen en de weging van verschillende sociale, economische en milieutechnische indicatoren zal in tijd en plaats op verschillende manieren plaatsvinden. Lange termijn ontwikkelingen in de maatschappij, de economie en het milieu zijn bovendien onderhevig aan grote onzekerheden en hebben sterk te maken met de voorkeuren tussen aard en omvang van te nemen risico's. De keuze voor een duurzaam energiepad kan niet beperkt worden tot het streven naar het zo snel mogelijk en zo hoog mogelijk opvoeren van het aandeel van duurzame bronnen in de energievoorziening. Een dergelijk streven gaat voorbij aan het feit dat de beschikbaarheid en betaalbaarheid van deze bronnen vooralsnog beperkt zijn. Bovendien zal grootschalige invoering van duurzame bronnen een geheel eigen milieulast met zich meebrengen, vooral vanwege de materiaalintensiteit en het landbeslag van deze bronnen. Vanwege deze normatieve en dynamische aspecten wordt in deze studie vooral gesproken over duurzame energiepaden en worden bepaalde energiebronnen niet per definitie uitgesloten van een bijdrage.

\section{De mogelijke rol van kernenergie}

Meningen over kernenergie lopen sterker uiteen dan meningen over andere energiebronnen. Heel wat energiedeskundigen beoordelen de inherente milieurisico's van de splijtstofcyclus, inclusief die met betrekking tot gezondheid en proliferatie, als volstrekt tegenstrijdig met elk denkbaar pad naar duurzaamheid. Anderen zijn ervan overtuigd, dat de voordelen van kernenergie, eventueel gedurende een bepaalde periode en onder bepaalde omstandigheden, zullen opwegen tegen de nadelen. Beide meningen zijn uiteindelijk gebaseerd op impliciete normen en waarden t.a.v. verantwoorde risico's. In dit rapport willen we feiten en meningen zo veel mogelijk gescheiden houden. De prestaties en risico's van kernenergie worden in sociaal, economisch en milieutechnisch opzicht op een rij gezet en er wordt voor gepleit deze prestaties en risico's te beoordelen in het licht van de prestaties en risico's van andere energiebronnen. Er wordt ook gewezen op de nationale omstandigheden en voorkeuren, die een legitieme rol van kernenergie in sommige landen of gedurende sommige perioden rechtvaardigen dan wel onmogelijk maken.

\section{S.2 De risico's van kernenergie}

\section{Duurzaamheidsindicatoren voor kernenergie}

De risico's van kernenergie hebben te maken met drie soorten van duurzaamheidsindicatoren:

- Economische risico's betreffen vooral de concurrentiepositie van kerncentrales in de elektriciteitsmarkt en de beschikbaarheid van nucleaire brandstofvoorraden.

- Milieurisico's betreffen vooral radioactief afval en reactorongevallen. 
- Sociale risico's betreffen vooral proliferatiegevaren en maatschappelijk draagvlak.

Deze drie risico's zijn geen onafhankelijke grootheden, in die zin dat het verkleinen van elk van deze risico's gevolgen heeft voor de andere soorten risico's. Zo zal de beperking van milieurisico's in het algemeen de economische risico's vergroten en de sociale risico's verkleinen.

\section{Radioactief afval}

Het bedrijven van het huidige mondiale reactorpark van ongeveer 430 reactoren ( $350 \mathrm{GWe}$ ) leidt tot een jaarlijkse hoeveelheid verbruikte splijtstof van ongeveer 5000 ton, waarvan 150 ton bestaat uit hoog radioactieve splijtingsproducten en actiniden. Blootstelling aan de straling van dit afval blijft gedurende millennia levensbedreigend. Langdurige opslag in geologische formaties is noodzakelijk. Geen land ter wereld is er momenteel in geslaagd een maatschappelijk aanvaardbare oplossing te implementeren. Onzekerheden over de integriteit van containers, de mogelijke contaminatie van grondwater, de stabiliteit van geologische formaties en de wenselijkheid van terughaalbaarheid blijven vragen oproepen, met als gevolg een gering draagvlak voor implementatie en lokaal verzet. Technologische en institutionele oplossingen kunnen dit probleem beter beheersbaar maken. De technologische oplossingen hebben betrekking op de reductie van de hoeveelheden afval door het benutten van een andere splijtstofcyclus en het omzetten van langlevende afvalproducten naar kortlevende. De institutionele oplossingen hebben betrekking op het inrichten van internationale opslagplaatsen met de bijkomende voordelen van schaal en controleerbaarheid. Ook het gebruik van kweekreactoren zou de hoeveelheid afval aanzienlijk terug kunnen brengen, maar de economische verwachtingen hiervan zijn momenteel negatief, terwijl de problematiek in de sfeer van proliferatie aanzienlijk toe kan nemen.

\section{Reactor ongelukken}

De risico's van reactorongelukken, waarbij schadelijke, radioactieve stoffen vrijkomen, hebben altijd een belangrijke rol gespeeld bij het reactorontwerp. Daarbij gaat het erom zowel de kans te verkleinen dat er ongelukken gebeuren, als ook de gevolgen van deze ongelukken te beperken. De kans op ongevallen is niet alleen sterk afhankelijk van het reactorontwerp, maar ook van de veiligheidscultuur van het verantwoordelijke energiebedrijf en het verantwoordelijke land. Aan beide fronten is er in de negentiger jaren van de vorige eeuw grote vooruitgang geboekt. De risico's verbonden aan het bedrijven van een zogenaamde RBMK-reactor onder het Sovjet regime ten tijde van het Tsjernobyl ongeluk zijn niet vergelijkbaar met die van een moderne PWR-reactor in bedrijf bij een gespecialiseerde Westerse elektriciteitsproducent. Dat betekent niet dat de kans op ongelukken verdwenen is, maar wel dat deze kans aanzienlijk kleiner is geworden en dat bovendien de omvang van mogelijke gevolgen sterk is afgenomen. Bovendien kan deze kans nog aanzienlijk kleiner gemaakt worden door een groter gebruik van passieve veiligheidskarakteristieken. Naast de evolutionaire ontwikkelingen gebaseerd op bestaande ontwerpen en bestaande ervaring, kunnen er bovendien meer revolutionaire concepten gehanteerd worden zoals de HTR, die een hogere inherente veiligheid vertegenwoordigen.

\section{Proliferatie van kernwapens}

De civiele benutting van kernenergie heeft op meerdere manieren een relatie met de militaire benutting van kernenergie, zoals de geschiedenis van de kernenergie industrie heeft aangetoond. Deze relatie kan een rol spelen op het vlak van de benodigde nucleaire kennis en onderzoeksfaciliteiten, in termen van verrijkingstechnologie die ook voor militaire toepassingen geschikt gemaakt kan worden, en tenslotte vanwege de geproduceerde plutonium splijtstof met mogelijk weglekken naar militaire doeleinden. Wat betreft de kennis- en onderzoekskant spelen naast de energietoepassingen ook andere, bijvoorbeeld medische, toepassingen een rol. In die zin is het volledig afzien van kernenergie geen afdoende oplossing voor problemen van nucleaire proliferatie, al krijgt de schaal van de problematiek daarmee een andere orde van grootte. Wat betreft de verrijkingstechnologie gaat het vooral om toegang tot fabricagetechnologie voor verrijking, en niet zo zeer om toegang tot verrijkinginstallaties. Wat betreft het verwerven van plutonium ligt het grootste gevaar bij eventuele opwerking, waarbij geconcentreerd plutonium vrijkomt, al betreft dat plutonium van een isotopensamenstelling die minder geschikt is voor wapenfabri- 
cage. Wat betreft proliferatie liggen er eveneens technologische en institutionele mogelijkheden om risico's te verlagen. De reeds jarenlang toegepaste CANDU reactor maakt geen gebruik van verrijkt uranium. Invoering van een thorium cyclus i.p.v. een uranium cyclus, zou eveneens voordelen bieden. Het is echter een illusie te denken dat elke vorm van synergie tussen civiele en militaire toepassingen van kernenergie voorkomen kan worden. Daarom blijven institutionele oplossingen op het vlak van internationale afspraken en controles via internationale organen de belangrijkste manier om proliferatierisico's te minimaliseren.

\section{Marktprestaties in de elektriciteitssector}

De kapitaalintensiteit en bouwtijd van kerncentrales vormt een nadeel voor de marktprestaties in een geliberaliseerde omgeving, waarbij de vereiste rentabiliteit van investeringen beduidend hoger ligt dan in een vroegere periode van nutsbedrijf het geval was. Bovendien zijn er geen schaalvoordelen in de constructie gerealiseerd vanwege de voortdurend hogere eisen wat betreft reactorveiligheid, stralingsbescherming en afvalverwerking. Nieuwe kerncentrales zijn onder de huidige omstandigheden in het algemeen een onrendabele investering. Dit geldt niet voor bestaande kerncentrales, die reeds afgeschreven zijn en bovendien een steeds hogere beschikbaarheidsfactor hebben bereikt. Levensduurverlenging van deze centrales is hiermee een zeer aantrekkelijke optie geworden. Verbetering van marktprestaties op lange termijn zal enerzijds afhangen van de fiscale aanpak van externe effecten van fossiele brandstoffen en anderzijds van de overschakeling van een stagnerende industrie gericht op unieke lokale constructies naar een groeiende industrie gericht op centrale fabricage van standaardmodules. Het is bovendien niet uitgesloten, dat nieuwe concepten gebaseerd op inherente veiligheid uiteindelijk ook tot grote kostenreducties kunnen leiden.

\section{Splijtstofvoorraden en -prijzen}

Gegeven de zwakke wereldmarkt voor kerncentrales vormen de beschikbare uraniumreserves geen limiterende factor voor kernenergie. Onder omstandigheden van forse groei zou de situatie overigens pas op lange termijn wezenlijk veranderen. Bovendien beperkt de grote spreiding van uraniumvoorkomens geopolitieke risico's van beschikbaarheid. Door de geringe afhankelijkheid van de concurrentiepositie van kerncentrales van brandstofprijzen zijn er ruime mogelijkheden voor voortgaande exploitatie van minder toegankelijke uraniumvoorraden.

\section{Maatschappelijk draagvlak}

Er bestaat momenteel onvoldoende maatschappelijk draagvlak voor kernenergie in veel westerse landen. De publieke perceptie van het uiteindelijke duurzaamheidsgehalte van fossiele en hernieuwbare bronnen hangt af van het gewicht dat impliciet aan de economische, ecologische en sociale duurzaamheidsindicatoren voor deze technologieën gegeven gaat worden. Naarmate de gevolgen van broeikasemisssies duidelijker worden en meer ervaring wordt opgedaan met grootschalige introductie van duurzame bronnen, kan de publieke waardering van de inherente risico's van bepaalde keuzes zich geleidelijk veranderen. Het geringe draagvlak voor kernenergie in de westerse wereld wordt bovendien niet vanzelfsprekend overgenomen in niet-westerse landen, waar de omstandigheden zowel economisch als ecologisch fundamenteel verschillen en waar de perceptie van maatschappelijk verantwoorde risico's heel anders kan liggen. Een andere houding t.a.v. kernenergie in deze landen en andere keuzes in termen van risicomanagement kunnen uiteindelijk weer gevolgen hebben voor het maatschappelijk draagvlak in Europa en Noord-Amerika. Een actieve opstelling van de overheid als transitiemanager naar een duurzame energievoorziening is in dit opzicht wenselijk.

\section{S.3 Generieke vergelijking met andere energieopties}

\section{Het belang van risicomanagement voor strategisch duurzaam energiebeleid}

De invoering van nieuwe technologieën op grote schaal brengt vrijwel altijd risico's met zich mee. Zo brengt kernenergie grote risico's met zich mee; maar dat geldt ook voor andere energieopties. De aard en omvang van deze risico's kunnen zeer uiteenlopen en bovendien zijn 
sommige risico's beter te beheersen door gerichte technologische ontwikkeling dan andere. Duurzame energiepaden zullen altijd in meerdere opzichten minder volmaakt zijn dan wenselijk uit oogpunt van optimale duurzaamheid. Op fundamenteel niveau zal het vooral gaan om het simultaan beantwoorden van drie basisvragen: hoe schoon is schoon genoeg (vooral bij fossiele brandstoffen en biomassa), hoe goedkoop is goedkoop genoeg (vooral bij duurzame energiebronnen) en hoe veilig is veilig genoeg (vooral bij kernenergie en $\mathrm{CO}_{2}$-opslag). $\mathrm{Er}$ is een duidelijke trade-off tussen de ecologische, economische en sociale risico's verbonden aan mogelijke duurzame energiepaden. Deze trade-offs zijn niet gemakkelijk in kaart te brengen, omdat de onderliggende technische en economische parameters m.b.t. conversie-efficiënties, brandstofprijzen, investeringskosten en milieugevolgen continu veranderen door technologische en sociaalpolitieke ontwikkelingen. De mogelijke rol van kernenergie voor een bepaald duurzaam energiepad moet dan ook vooral gezien worden in het licht van generiek risicomanagement, waarbij een vergelijking met de risico's van andere energieopties voorop staat. Een diepgaande en kwantitatieve analyse van duurzaamheidsindicatoren voor alle beschikbare energietechnologieën valt buiten de reikwijdte van deze studie. Volstaan wordt met een indicatief en kwalitatief overzicht.

\section{Milieurisico's}

De milieurisico's van fossiele brandstoffen hebben betrekking op klimaatverandering, verzuring en lokale luchtverontreiniging. De verbranding van biomassa heeft alleen betrekking op verzuring en lokale luchtverontreiniging, voor zover het gaat om hernieuwbaar geproduceerde biomassa. Het traditioneel verbruik van biomassa in ontwikkelingslanden is vaak niet op hernieuwbare basis en wordt bovendien gekenmerkt door ernstige luchtverontreiniging binnenshuis. Er zijn veel technologische mogelijkheden die op termijn een groot aantal van deze gevolgen kunnen voorkomen, maar waarvan de economische consequenties nog niet duidelijk zijn. Het gaat dan om nieuwe conversietechnologie in de sfeer van brandstofcellen en waterstof met bijbehorende voor- en nabehandeling. Voor de oplossing van het klimaatprobleem zal een vorm van $\mathrm{CO}_{2}$-opslag gekozen moeten worden, die milieutechnisch aanvaardbaar is. De milieurisico's van duurzame energiebronnen hebben vooral te maken met de grote materiaalintensiteit en het hoge landgebruik van deze opties indien grootschalig ingevoerd. De gevolgen van grootschalige, geteelde biomassa zijn het grootst en meest complex vanwege bijkomende problemen op het gebied van biodiversiteit, genetische modificatie, gebruik van water en inzet van kunstmest en bestrijdingsmiddelen. Daarnaast kunnen er allerlei sociale complicaties optreden in termen van alternatief, kleinschalig landgebruik door de lokale bevolking. Windenergie en zonne-energie leggen ook een hoog beslag op ruimte, maar voorlopig gaat het daarbij om ruimte met weinig alternatieve bestemmingen, m.n. voor zover het off-shore wind en zonne-energie in de gebouwde omgeving of woestijnachtige streken betreft. De milieurisico's van kernenergie verschillen in alle opzichten van bovengenoemde aspecten.

\section{Economische risico's}

De economische risico's van fossiele brandstoffen hebben betrekking op voorzieningszekerheid en beschikbaarheid. Beide risico's vertalen zich uiteindelijk in risico's voortkomend uit onvoorziene ontwikkelingen in brandstofprijzen zowel qua niveau als qua instabiliteit. De risico's van voorzieningszekerheid zijn daarbij groter dan van beschikbaarheid. Bovendien gelden deze risico's in veel sterkere mate voor gas en olie dan voor kolen. De economische risico's van kernenergie en stromingsbronnen hebben daarentegen vooral te maken met de kapitaalintensiteit van de technologie. In een zich liberaliserende energiesector is de druk op rentabiliteit fundamenteel hoger dan in het verleden als nutsbedrijf het geval is geweest. Voor kernenergie komt daarbij dat lange termijn risico's moeilijk te verzekeren zijn zonder staatsgaranties. Daar staat tegenover dat fiscale maatregelen die bedoeld zijn om de externe effecten van fossiele brandstoffen te belasten in beginsel sterk in het voordeel van zowel duurzame energie als kernenergie zouden kunnen uitvallen. De concurrentiepositie van sommige duurzame bronnen zoals PV is momenteel echter dermate zwak, dat fundamentele technologische ontwikkelingen noodzakelijk zijn 
om zelfs bij hoge fiscale voordelen nog een rol van betekenis te kunnen spelen. Voor kernenergie ligt het keerpunt veel meer binnen bereik.

\section{Sociale risico's}

Het belang van sociale risico's wordt vaak onderschat in discussies over duurzame technologie, behalve wellicht in het geval van kernenergie. Deze risico's hebben te maken met maatschappelijke voorkeuren t.a.v. technologische infrastructuur en marktordening, maatschappelijke stabiliteit, en de publieke opinievorming rond, en kennis en expertise in, energietechnologie en het daaraan gekoppelde vertrouwen in deskundigen. Een maatschappelijke inrichting en voorkeurspatroon dat sterk neigt naar decentrale oplossingen en lokale autonomie zal op subtiele maar doorslaggevende manier invloed hebben op technologie-ontwikkeling en keuze van energie-opties. Het grote draagvlak voor PV en het zwakke draagvlak voor kernenergie heeft alles te maken met de publieke perceptie van de sociale risico's rond deze technologieën. De huidige problematiek rond on-shore windturbines en de mogelijke problematiek rond de maatschappelijke aanvaardbaarheid van $\mathrm{CO}_{2}$-opslag verdienen in dit opzicht meer aandacht. In een liberale markt zullen aanbieders ook op de percepties van klanten leren inspelen met grote gevolgen voor de wijze waarop overheden invulling kunnen geven aan duurzaam energiebeleid. Het is van groot belang dat overheden en publiek zich van deze sociale risico's bewust zijn en deze risico's bewust meenemen bij het maken van evenwichtige keuzes voor een duurzaam energiepad.

\section{S.4 De rol van kernenergie voor een mondiaal duurzaam energiepad}

\section{Belangrijke transitierol in de periode tot 2020}

Kernenergie speelt nog steeds een belangrijke rol bij het formuleren van lange termijn mondiale energiescenario's. De reden hiervoor is de substantiële huidige bijdrage van kernenergie in een groot aantal OECD-landen. Op mondiale schaal voorziet kernenergie in $16 \%$ van de elektriciteitsvoorziening. De milieuproblemen rond capaciteitsuitbreiding van fossiele centrales en de verbeterde prestaties en leeftijdsverlenging van kerncentrales zorgen ervoor dat deze rol behouden blijft tot ver na 2010. Daarnaast is er nog steeds een aantal prominente OECD-landen die blijven investeren in een nucleaire toekomst, terwijl de snel groeiende economieën van Zuid- en Oost-Azië een gematigd positief standpunt innemen, al zal er op korte termijn geen sprake zijn van forse investeringen. Op het pad naar duurzaamheid zijn er veel energie-opties, die een rol zouden kunnen spelen in een lange termijn blauwdruk voor een duurzame energievoorziening rond het midden van deze eeuw, maar er zijn weinig energie-opties, die een prominente transitionele rol zouden kunnen spelen op de weg hiernaartoe tot 2020, zeker als de broeikasproblematiek en voorzieningszekerheid een sterk sturende invloed krijgen. Het recente derde evaluatierapport van de IPCC heeft de mogelijke rol van verschillende energietechnologieën tot 2020 gekwantificeerd en kwam tot de conclusie dat kernenergie in absolute zin de grootste bijdrage zou kunnen leveren aan oplossing van het klimaatprobleem. In feite speelt kernenergie in dit opzicht vandaag de dag al een belangrijke transitionele rol.

\section{Determinanten van de nucleaire concurrentiepositie na 2020}

De lange termijn toekomst van kernenergie hangt af van ontwikkelingen in de concurrentiepositie van fossiele en duurzame alternatieven en in de commerciële levensvatbaarheid van de nucleaire industrie zelf. De concurrentiepositie van fossiele brandstoffen wordt sterk bepaald door fiscale maatregelen om de externe effecten van fossiele brandstoffen op de markt te internaliseren, terwijl de concurrentiepositie van duurzame alternatieven vooral afhangt van technologische ontwikkelingen en van de door consumenten ervaren meerwaarde van groene stroom. De nucleaire industrie zal bovendien een ingrijpende herstructurering van constructiebedrijf van unieke objecten naar assemblage-industrie voor standaardproducten moeten doormaken. Alleen onder deze omstandigheden kan verdere technologische ontwikkeling een belangrijke rol van kernenergie op langere termijn waarborgen. Het is de vraag of de transitierol van kernenergie in de periode tot 2020 nog voldoende kan groeien om deze herstructurering te kunnen realiseren. Dit zal sterk afhangen van de voortvarendheid waarmee internationale klimaatverdragen worden 
afgesproken en uitgevoerd, en het gewicht dat vraagstukken van voorzieningszekerheid en leveringsbetrouwbaarheid gaan krijgen op de politieke agenda.

\section{Kernenergie als 'hedging' optie}

Risicomanagement op de weg naar een duurzame energievoorziening heeft niet alleen te maken met een continue evaluatie van de relatieve risico's van verschillende energietechnologieën, maar ook met de mogelijkheden om deze te beïnvloeden door gericht onderzoek. Kernenergie wordt enerzijds gekarakteriseerd door een transitionele rol in de periode tot 2020 voor tenminste een aantal landen, en anderzijds door concrete mogelijkheden om de risico's ervan verder te beperken in de periode na 2020. Hierin verschilt kernenergie van opties die ofwel een veel kleinere transitierol zullen kunnen spelen op de kortere termijn (m.n. duurzame energie) ofwel veel meer onzekerheid meebrengen voor wat betreft de langere termijn (m.n. fossiele brandstoffen). Deze kenmerken maken kernenergie een optie voor zogenaamde 'hedging' strategieën, waarbij landen bereid zijn een duidelijk risico te nemen voor de kortere termijn, terwijl ze zich tegelijkertijd voorbereiden deze risicoblootstelling voor de lange termijn te verminderen. Landen zullen wat dit betreft heel verschillende keuzes maken afhankelijk van economische omstandigheden en nationale beschikbaarheid van energiedragers. Dit houdt in, dat landen ook verschillende portfolio's zullen kiezen wat betreft inzet van technologie en onderzoeksinspanningen. Voor zover landen hierbij heel bewust een 'hedging' strategie hanteren, betekent dit, dat kernenergie in ieder geval voor sommige landen, en voor sommige periodes, een rol gaat spelen bij het volgen van een pad naar een duurzame energievoorziening.

\section{Drie scenario's voor kernenergiebeleid en -onderzoek in Nederland}

De voorgenomen sluiting van Borssele wordt soms gezien als het einde van het nucleaire vraagstuk in Nederland. Dit is in meerdere opzichten misleidend. In de eerste plaats zijn er nog twee nucleaire installaties in Nederland open, die allebei internationaal een belangrijke plaats innemen. NRG in Petten voorziet het merendeel van de ziekenhuizen in Europa van isotopen voor medisch gebruik en URENCO levert een belangrijk aandeel in de mondiale markt voor verrijkt uranium. In de tweede plaats ligt het voor de hand dat in de nabije toekomst alle elektriciteit gelabeld gaat worden. Dit opent ook een Nederlandse markt voor leveranciers van kernenergie aan klanten die duidelijk pro-kernenergie zijn of belang hebben bij (mogelijk) goedkope basislast. Een scenario van verdere afbouw zal naast beleidsstandpunten over nucleair afval ook een standpunt over deze twee onderwerpen moeten bepalen. In dit scenario wordt alle onderzoek beperkt tot het oplossen van de afvalerfenis. Voor zover Nederland invloed wil houden bij het bepalen van de Europese agenda op het gebied van kernenergie-onderzoek, zou het raadzaam zijn dit scenario uit te breiden naar een scenario van voorzichtige stilstand, dat bestaande $\mathrm{Ne}$ derlandse onderzoeksprogramma's een duidelijke plaats geeft binnen Europese programma's, die zich sterk richten op het vergroten van de duurzaamheid van kernenergie, b.v. wat betreft levensduurverkorting en volumebeperking van radioactief afval of wat betreft inherent veilige en proliferatie-resistente reactorontwerpen. In dit scenario is het raadzaam de sluiting van Borssele uit te stellen teneinde de introductie van alternatieve emissie-arme technologie gefaseerd tot stand te brengen. Tot slot is het op termijn niet uitgesloten dat Nederland zich wil voorbereiden op een meer actieve opstelling voor beïnvloeding van wereldwijde ontwikkelingen wat betreft kernenergie. Een dergelijk scenario van actieve betrokkenheid zou inhouden, dat Nederland naar wegen gaat zoeken om de duurzame prestaties van kernenergie op termijn ingrijpend te verbeteren om te voorkomen dat voortijdige en suboptimale beslissingen over vergrote inzet van kernenergie in Europees verband genomen gaan worden. Dit scenario zou dichterbij kunnen komen, als er in de komende tien jaar een nucleaire renaissance plaats gaat vinden in de Verenigde Staten of Oostelijk Azië, terwijl in Europa de vooruitzichten voor de inzet van schone fossiele centrales afnemen en de zorgen over voorzieningszekerheid toenemen. Een dergelijk scenario zou niet alleen betekenen dat er additionele fondsen voor innovatief onderzoek ter beschikking moeten komen, maar ook dat er hernieuwde aandacht komt voor het Nederlands kernenergiebeleid in het kader van een Europese elektriciteitsmarkt. 


\section{INTRODUCTION}

\subsection{Purpose and scope of study}

Nuclear energy remains a controversial issue for public policies on energy and environment, particularly so in the Netherlands. The issue of climate change has provided new arguments for its reappearance on the international political agenda. Recent policy directions in the USA show that this reappearance is not just wishful thinking of the nuclear establishment. To assess the potential role of nuclear energy in establishing sustainable energy paths ECN Policy Studies and the Institute for Environmental Studies of the Free University of Amsterdam have made a concise inventory of facts and opinions regarding the benefits and risks of nuclear energy. The scope of this survey is essentially global, although it is indicated what the conclusions could mean for policy and research regarding nuclear energy in the Netherlands.

\subsection{Concept of sustainable energy paths}

The concept of sustainability has a long and complex history, which evolved from an ecological and physical focus in the early 1970's towards an economic and social interpretation in the late 1980's. The 1987 Report of the Brundtland Commission played a catalytic role in promoting this transition. Sustainable development was defined as a dynamic development process in which the needs of the present generation are met without compromising the ability of future generations to meet their own needs. The idea of sustainability suggests that goals of economic growth can be effectively combined with goals of social welfare and environmental quality. Energy is not only the engine of economic growth, but also the source of major environmental emissions. It is therefore not surprising that the energy sector occupies a central role in discussions on sustainability.

An energy system can be viewed as sustainable if it succeeds in providing the energy to allow sufficient and equitable economic growth without seriously compromising the environment. Since sustainable development is a dynamic process, we prefer to use the term sustainable energy paths rather than sustainable energy systems. The former term indicates that the role and perception of energy technologies may change along the road to an increasingly sustainable society and that we are looking at a social transition process rather than a final technological blueprint. In addition, the emphasis on the process of sustainable development also allows consideration of the social and institutional changes required to bring about sustainability. Often sustainable development is implicitly understood to incorporate social and institutional characteristics that allow effective participation of citizens. These social and institutional characteristics typically refer to the process followed in reaching economic and environmental goals. Ultimately they may play an equally important role in defining sustainable energy paths as the economic and technical features of energy systems.

\subsection{Normative aspects of sustainability}

The sustainability of a particular energy system or energy path is in principle not an objectively measurable qualification of an empirical nature. There are two essential reasons why sustainability is a normative concept. The first reason has to do with the many dimensions of economic, environmental and social indicators of sustainability. Both the level of income and the distribution of income are economic indicators of importance to define sustainable development, but the relative weight of each goal is a matter of subjective judgement. With respect to environmental impacts the difficulties are equally complex, because the impacts of different en- 
ergy systems are very diverse. When it comes to social indicators of sustainability, it may even be difficult to define quantitative indicators. Measuring the sustainability of particular energy technologies with a set of economic, environmental and social indicators is not an objective, empirical task but a normative, subjective task involving weighting indicators that are based on unrelated units of measurement or dissimilar qualitative assessments.

Secondly, uncertainty and risk characterise long term developments in the economy, the environment and society. Indicators of sustainability are not only difficult to compare, they are also characterised by fundamental uncertainties. Sustainable development therefore has a lot to do with choosing for one kind of risk rather than another. To reduce environmental risks generally has a negative impact on immediate economic gains and to promote the certainty of immediate economic growth generally means less room for environmental concerns. This is primarily a social choice between acceptable levels of different economic risks and acceptable levels of different environmental risks and not a scientific evaluation of an empirical problem.

\subsection{Sustainable energy paths and renewable energy sources}

It may be tempting to view sustainable energy paths simply as the construction of a road map to increase the share of renewable energy sources and decrease the share of fossil fuels in the total share of energy sources. But this can be misleading. First, in many respects these sources are presently unable to fulfil a basic characteristic of sustainable development. They can not accommodate the needs of the present generation without jeopardising economic performance. Their availability and affordability is limited. Secondly, renewable energy sources have their own share of environmental problems and leave their own environmental footprint, mainly because they tend to be very material- and land use-intensive. This puts them in a different league of environmental problems than fossil fuels, but it should not exempt them from environmental evaluation. Certainly, sustainable energy paths will show an increasing share of renewable energy sources, but the major question for the next two decades of the road map towards sustainability may be more related to how to fill the much larger gap remaining.

\subsection{Role of nuclear energy in sustainable energy paths}

Opinions about the role of nuclear energy for sustainable energy paths are notoriously strong. Many energy analysts view the inherent environmental risks of the nuclear fuel cycle, including those related to human health, as contradictory to any conceivable path towards sustainability. Others are convinced that the benefits of nuclear energy systems will sooner or later lead to a prominent nuclear role in sustainable energy paths. Unfortunately, such certainties cannot be based on known facts about nuclear and competing energy sources. They are based on implicit value judgements. In the present paper we will try to separate the analysis of the more objective facts from the more normative choices. We will evaluate the performance of nuclear energy with respect to several indicators of economic, environmental and social risks, but we will also point out that societies must ultimately compare these nuclear risks with the long-term risks of other energy sources in order to make balanced choices. We will also point out that there may be national circumstances and preferences on the road towards sustainability, which will favour or discredit a legitimate role for nuclear energy in particular nations during particular periods.

\subsection{Key sources of background material}

When the issue of climate change became an important driving force for energy policy decisions, nuclear energy returned as a serious contender for fossil fuel options. Not surprisingly this has led to a number of recent publications on the sustainability aspects of nuclear energy. Among these are notably the reports by the International Energy Agency (OECD/IEA, 1998), the Nuclear Energy Agency (OECD/NEA, 2000), the International Atomic Energy Agency 
(IAEA, 2000), and the British Royal Society (Royal Society, 1999). These publications have served as important background material for the present study. In addition, two major global assessments by international panels of scientists have addressed the future of the energy sector from the point of view of climate change. One is the result of a joint effort by UNDP, UNDESA and WEC and is known as the World Energy Assessment Report (UNDP/UNDESA/WEC, 2000). The other is the Third Assessment Report of Working Group III of the Intergovernmental Panel on Climate Change (IPCC, 2001). These two reports have also provided important background material for the conclusions reached here. 


\section{NUCLEAR ENERGY'S RISKS}

The indicators determining the level of sustainability of any energy option can be categorised in three classes: environmental, economic and social. Sustainability indicators for nuclear energy in particular are among all of these categories.

Nuclear energy faces numerous problems, the three predominant of which are radioactive waste, reactor accidents and nuclear proliferation. In an analysis of the role of nuclear energy in establishing sustainable energy paths, these ought to be carefully addressed. Other aspects that ought to be assessed in this context are nuclear energy's market competitiveness and the availability of nuclear energy resources. A problem with a different dimension, but of equally negative implications, is nuclear energy's generally unfavourable public opinion.

Radioactive waste and reactor accidents are environmental indicators for the sustainability of nuclear energy. Nuclear energy's market competitiveness and its natural resources have an economic dimension. Its characteristics in terms of public opinion and nuclear proliferation are social (or institutional) in nature. These six aspects of nuclear energy, cast into three different types, are concisely reviewed in this section, predominantly in terms of the potential risks they involve.

\subsection{Radioactive waste}

The problem nuclear energy faces regarding nuclear waste is vast, and according to many prevalent among its various handicaps. Whether nuclear power will in the future be phased out, be expanded or simply stagnate, a satisfying solution needs to be found for the risks induced by the radioactive waste generated to date. One can basically distinguish between two types of nuclear waste: spent fuel and radioactive emissions, both produced by nuclear power plants in normal operation. These do not include the waste and radioactive contamination potentially produced as a result of abnormal reactor operation, e.g. in the occurrence of a severe accident, as described in section 2. These two kinds of waste are dealt with in two opposite manners. The attitude to the former is generally that of concentration and protection. To the latter mostly the principle of dilution is applied. Since it has been demonstrated that, in any objective scientific sense, emissions do not pose exceptional risks, they are first briefly portrayed below. The risks involved with highly radioactive spent fuel, posing potentially considerable safety and health risks, both at present and for generations in distant futures from now, are then concisely analysed. But before doing so, we indicate where precisely, in normal reactor operation, waste problems occur in the nuclear fuel cycle.

\subsubsection{Overview of the nuclear fuel cycle}

Figure 1 shows a schematic view of the nuclear fuel cycle. The squares indicate its main stages: uranium mining, fuel fabrication, reactor operation, spent fuel management and, potentially, reprocessing (other intermediate stages, such as uranium conversion and enrichment in between uranium mining and fuel fabrication, are omitted for reasons of exposition). The figure shows both the so-called 'open fuel cycle', in which the used fuel rods are directly disposed of as spent fuel, and the so-called 'closed fuel cycle', in which the spent fuel is reprocessed and the produced plutonium (as well as the unburned uranium) recycled for new fuel fabrication. Since not all countries apply the closed fuel cycle, the latter (additional) stage is depicted in dashed lines. At basically every stage of the fuel cycle, some sort of radioactive waste is generated. Circles indicate the radioactive waste produced by the fuel cycle, at its various phases. The two most 
predominant and/or controversial of these are usually considered to be radioactive emissions (depicted by vertically dashed circles) and spent fuel (horizontally dashed circles).

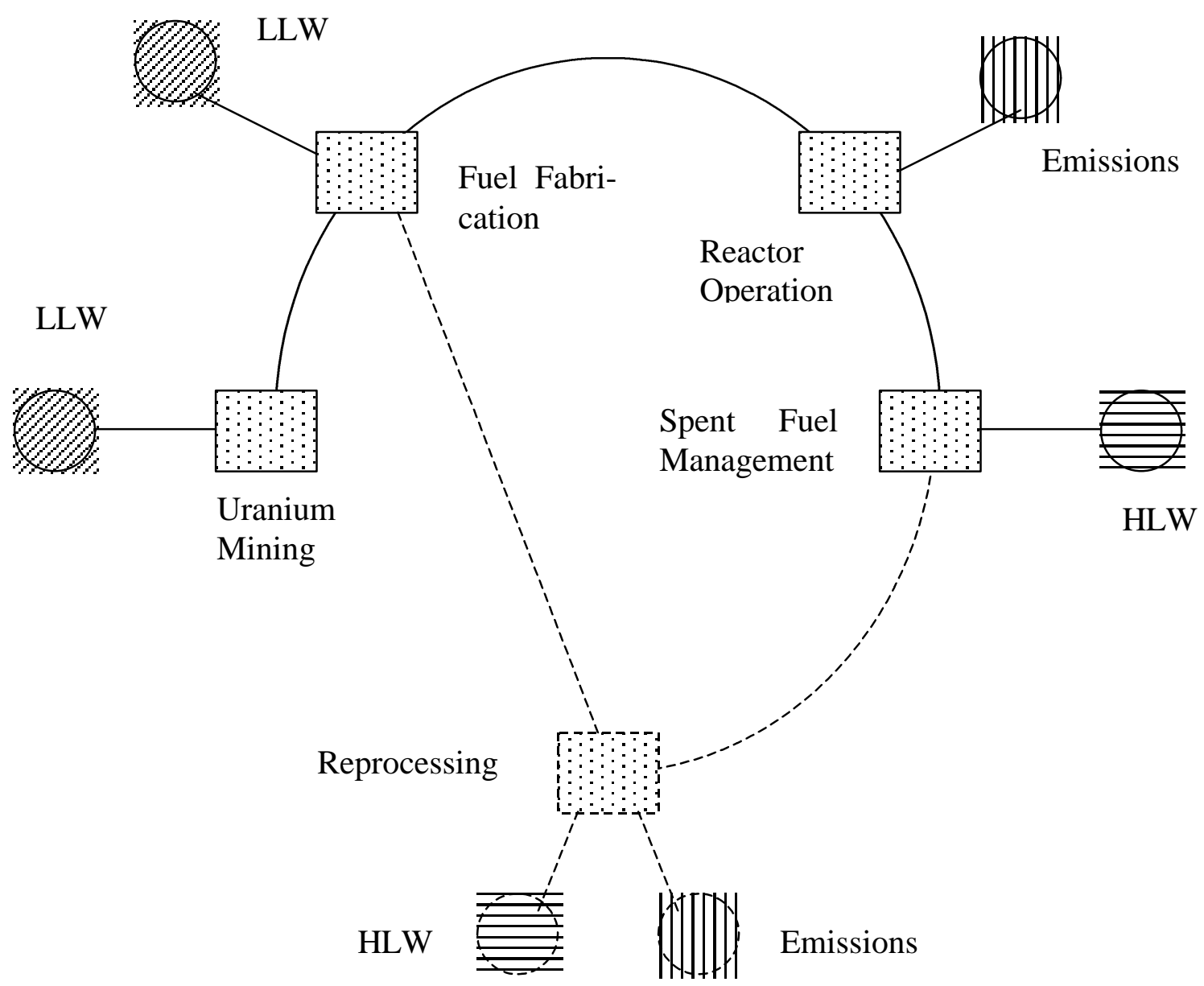

Figure 2.1 Schematic View of the Nuclear Fuel Cycle

Spent fuel is the most problematic form of waste produced, since it generates heat until years after having been de-loaded from the reactor core, while remaining highly radioactive for several hundred thousands of years. It is therefore referred to as high level waste (HLW). It obtains its high and long-lasting radioactivity during reactor operation, since fission products (from nuclei breaking into two or more parts) and minor actinides (heavy isotopes created by uranium nuclei capturing neutrons) are produced that have high radiation levels with long half-lives. The particles emitted by these elements have a destructive impact on the living material that is exposed to it. Human exposure to radiation can cause numerous medical effects, varying from the burning of human skin and tissue, the development of cancers, or immediate death, depending on the level of radio-toxicity of the materials concerned. HLW of basically equivalent nature is produced in both open and closed fuel cycles, although in the latter the quantities involved are smaller in comparison to the volumes produced in the former, that is, if expressed per amount of electricity generated.

In addition to HLW, low level waste (LLW) is generated at various other phases, such as the mining and fuel fabrication stages of the fuel cycle (depicted by diagonally dashed circles in Figure 2.1). This waste is generally rather large in volume, but with radioactivity levels only moderately exceeding natural levels. LLW materials can be protected in rather straightforward ways and loose much of their radioactivity in relatively short periods of time. They therefore pose just modest risks for human health. Similar LLW materials have to be managed at the stage 
of the decommissioning of nuclear power plants. After the nuclear power plants' lifetime, at present about 30 years (modern plants typically are designed for lifetimes of 40 years or more), parts of the plant - among which the reactor vessel, the pipelines and the concrete used for plant construction - are contaminated with traces of radioactive elements. While constituting generally relatively large volumes, these LLW sources pose remote dangers in terms of long-term radio-toxicity.

\subsubsection{Radioactive emissions}

Gaseous or liquid radioactive emissions of nuclear power plants are generally very low. Even the human exposure levels as a result of emissions from reprocessing plants, such as the ones in La Hague (France) and Sellafield (UK), are in general considerably lower than those resulting from natural radioactivity. The International Commission on Radiological Protection (ICRP) makes recommendations on the protection of people from the harmful effects of ionising radiation. These are reflected in national regulations. The standards developed by the ICRP are based on limiting, by all reasonable means, the risks of health effects, adopting a precautionary approach, but not on eliminating that risk entirely (OECD/NEA, 2000). The central guideline is the so-called ALARA principle (i.e. keeping doses As Low As Reasonably Achievable, economic and social factors being taken into account).

The dose limits recommended by the ICRP are $1 \mathrm{mSv}$ per year for exposure of the public, and $20 \mathrm{mSv}$ per year for exposure of workers in the nuclear industry. It is instructive to compare these limits with the average dose people receive from natural background radiation of about 1$3 \mathrm{mSv}$ per year. Actual figures of natural radiation exposure can vary widely with location, to even an order of magnitude higher for some populations. Table 2.1 shows the average shares of annual human exposures to radiation from natural and artificial sources. The natural dose of radiation people receive is not only dependent on the kind of soil they live on, but also on the height at which they reside. People living at $4000 \mathrm{~m}$ (like Bolivians in La Paz) receive, solely as a result of cosmic radiation, already some $2 \mathrm{mSv}$ per year. On an average intercontinental flight, one easily obtains a radiation exposure of some $0.1 \mathrm{mSv}$, so that aeroplane crew is readily exposed to annual radiation levels an order of magnitude higher than received by the general public. Generally, one can safely argue that the radioactive dose levels to which the public is exposed as a result of natural sources, first of all, and medical sources, in the second place, are much higher than those resulting from nuclear power generation (see Table 2.1).

Table 2.1 Average shares of annual exposures to radiation from natural and artificial sources

\begin{tabular}{|c|c|c|}
\hline Source & & Average exposure \\
\hline Radon & & $48.2 \%$ \\
\hline Terrestrial & & $25.6 \%$ \\
\hline Cosmic & & $14.5 \%$ \\
\hline Man- & medical & $11.3 \%$ \\
\hline made & nuclear power & $0.4 \%$ \\
\hline
\end{tabular}

Source: OECD/NEA, 2000.

\subsubsection{Spent fuel}

At present, the global nuclear park of some 430 reactors and about 350 GWe capacity produces an annual amount of spent fuel of about 5,000 tons, containing some 150 tons of highly radioactive fission products and minor actinides. The spent fuel is first stored on-site in pools to cool down, since the used fuel elements continue producing considerable amounts of heat after they have been de-loaded from the reactor. Whereas most heat is dissipated after a couple of years, the fuel rods remain highly radioactive for thousands of years. Some isotopes contained in the spent fuel remain even radioactive for much longer periods of time. The central question is what to do with this radioactive spent fuel, over such a long time lapse. 
The most viable option today for managing the high level wastes produced is to store them deep underground in geological depositories. Studies are being performed continuously that demonstrate the long-term reliability of geological depositories. To this date, however, no country has implemented yet a permanent solution for final nuclear waste disposal and/or storage. The main issue concerning this storage option is whether the geological isolation offered by underground layers will be sufficient. One of the other reasons that governments delay on this issue are the uncertainties that remain about the integrity of spent fuel canisters, over a required period of thousands of years. Over short time periods (e.g. centuries) no uncertainties on either geological or container integrity seem to exist (irrespective of the problems that are often faced today with proper containment of waste above ground at nuclear power sites). Most options for underground nuclear waste depositories are therefore, in general terms, accepted to be safe. There is even a high degree of agreement among scientists on their long-term reliability. It is mainly the mere time length over which integrity is required that casts doubt on storage acceptability. The main fear is that canisters, as a result of corrosion, start to leak after many centuries or thousands of years, and consequently, due to a possible lack of geological containment, contaminate ground water. As a result of this, future generations could experience its potentially harmful impact. Research needs to be pursued into the long-run reliability of a variety of the current depository options.

The role of the public opinion in governments' decisions on burying waste underground, in the form of local opposition, is a determinant factor, characterised by the commonly used expression 'Not in My Back Yard' (known as NIMBY). The Yucca Mountain underground site in Nevada, proposed to permanently dispose of all US spent fuel produced until about the year 2010, will not suffice for waste produced after that date. Given the current political and public opinion opposition the Yucca Mountain repository faces today, the search for supplementary sites constitutes undoubtedly an enormous challenge. For similar political and public opinion reasons, also in other countries, (new) storage sites can probably be found with difficulty. It seems that only a radical shift in the attitude towards nuclear waste can alter the impasse the waste disposal currently seems locked in.

The problem of nuclear waste, however, ought to be considered dynamic. Solutions that contribute to ease the waste problem, to at least some extent, seem to be available. At least two channels seem to exist through which the nuclear waste hurdle could be mitigated: (1) reducing the radioactive lifetime of nuclear waste, and thereby the radiotoxicity and total amount of harmful nuclear waste produced, and (2) organising waste disposal internationally.

Technologies exist, or can be developed, that allow shortening the lifetime of radioactive waste (see Figure 2.2). The actinides from spent nuclear fuel remain radiotoxic for hundreds of thousands of years (top line), but this period can be reduced to a thousand years or less. It has been ascertained that with improved recycling techniques the vast majority of the actinides can be removed from the spent fuel. The actinide radiotoxicity that then remains is about a thousand times smaller (lower thin line). The separated actinides can be included in the fuel of a special actinides burner. The waste from such an actinides burner - which only exists on the drawingboard as of yet - has a waste characteristic as shown by the upper thin line. In principle, this waste can also be recycled further, so that the actinide radiotoxicity curve of the eventual waste will lie somewhere in the shaded area, depending on the recycling strategy chosen. Of course, the waste leaving a nuclear reactor also contains a short-lived component resulting from fission products. The corresponding radiotoxicity curve is also included in the graph (dotted thick line). For fission products, lifetime reductions options seem less obvious. At any rate, it still follows from the above that the total radiotoxicity of nuclear waste (summing that of actinides and fission products) can probably be reduced to about a few hundred years, that is, when appropriate $R \& D$ is initiated in these waste reduction options. Indeed, the waste problem would be mitigated considerably, were these options applied on a large scale. 
There is also potential for designing fuel cycles that reduce the amounts of nuclear waste. New nuclear technologies exist and/or can in principle be developed, such as the use of thorium as fuel - e.g. in fast neutron reactors - which address the waste problem. More advanced ideas, such as the use of accelerator-driven systems, e.g. in waste transmutation or incineration programs, could also further mitigate the waste problem. While some fission products might never become transmutable into less harmful materials, at CERN it has been demonstrated that certain of them can be incinerated by using beams of fast moving particles. Although some of the current concepts proposed are far from being realised, considerable scope seems to exist for opportunities to reduce the presently produced amounts of nuclear waste. These ought therefore to be further investigated.

It could be interesting revisiting the establishment of a plutonium economy, involving the reprocessing of spent fuel (as indicated in Figure 2.1). The use of reprocessing, as well as the establishment of breeder reactors allowing for enhanced levels of plutonium generation, was in the 1970s judged to be capable of providing virtually unlimited amounts of nuclear energy resources, required to face expensive and potentially small future reserves of uranium. Meanwhile, uranium has proved to be much more abundant, at relatively low prices, than initially foreseen, so that the application of reprocessing lost an important rationale. 


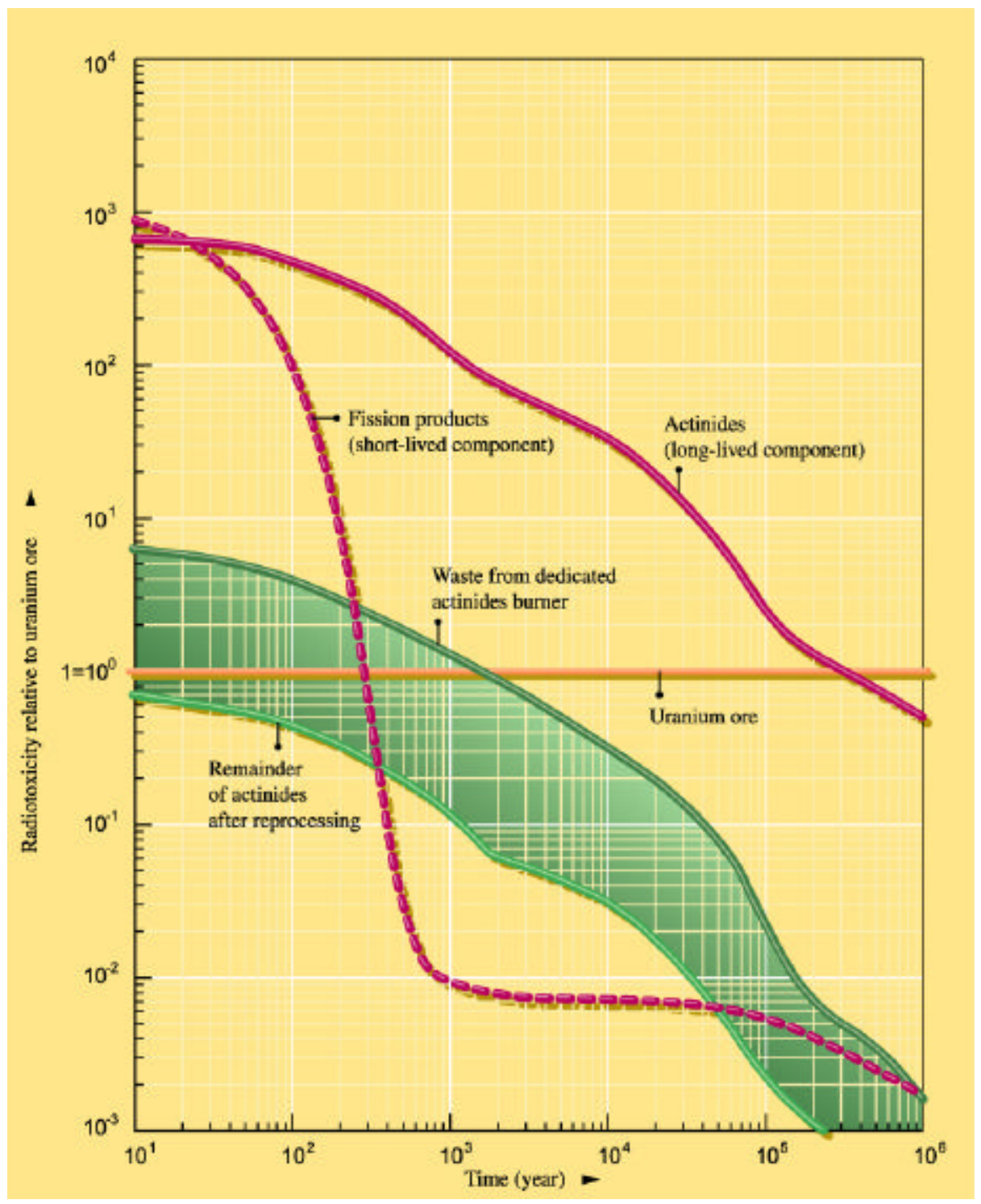

Figure 2.2 Shortening the lifetime of radioactive waste

Another advantageous characteristic of reprocessing, however, is that it involves lower volumes of highly radioactive spent fuel per unit of electricity generated than in the open fuel cycle. This is one of the arguments why some countries still favour reprocessing today, irrespective of the generally somewhat more elevated costs. Because of its favourable properties, in terms of reduced quantities of high level waste produced, reprocessing could regain interest in the future. Despite its potential to eliminate some of the storage needs, reprocessing is currently rather controversial, and only applied by a restricted number of countries, among which France, Japan, Russia and the UK. Since reprocessing involves the separation of plutonium, the storage volume gains would presumably be at the cost of additional risks for proliferation. That is why - in association with its relatively high costs, and the presence of enormous stockpiles of plutonium already from military origins - the US, since the Carter Administration, has opposed rather fiercely the reprocessing of spent fuel.

It would be erroneous, however, to assume that nuclear waste problems can be avoided entirely. One of the proposed methods to more effectively address the waste problem would be to internationally organise the storage of spent fuel. It is highly inefficient for every country with nuclear reactors to have its own waste storage facility. The establishment of an internationally 
monitored waste repository (IMWR) has been suggested in the past, e.g. in countries such as Australia, China and Russia. Were nuclear energy to be expanded in many countries in the future, IMWRs seem indispensable. Such IMWRs would provide economies of scale, creating opportunities for the reduction of storage costs. The reduction of the number of disposition sites world-wide, via centralised waste storage, also allows for more effective storage protection and safeguarding, and reduces the accessibility to fissionable and radioactive sources for military or terrorist diversion, thereby mitigating proliferation risks and contributing to ensuring international security. Even relatively small amounts of radioactive material, whether of military, civil or medical origin, can provoke tremendous havoc when employed by terrorists. This is one of the rationales why this material should be concentrated at as few locations as possible, while being safeguarded tightly and monitored internationally, instead of being dispersed over numerous places each possessing a certain probability of failure against terrorist access and diversion. Chances for the realisation of IMWRs, however, at present seem remote. Given the current geopolitics, it would be tedious to decide where an IMWR would be located.

In addition to these two main options for mitigating the nuclear waste problem, a number of other elements can possibly play a significant role in reducing this obstacle. First, more effort can be put into informing the public on the manageability of storing nuclear waste over long periods of time. Indeed, several options exist for burying waste safely underground over long time frames. Second, progress continues to be achieved in designing increasingly safe canisters and containers, that are unlikely to release any substance enclosed over thousands of years and beyond. Third, it is possible to create a reversibility of waste stored underground. This leaves open the option to retrieve the waste when the integrity of canisters proves insufficient, or if future technological developments allow for a more appropriate way to tackle or store the waste efficiently.

\subsection{Reactor accidents}

One of the intrinsic characteristics of nuclear energy, in the past as well as today, is the occurrence of reactor incidents and accidents. The nuclear industry is keen, on the one hand, to reduce the probability that accidents occur, and to minimise their consequences, whenever they occur. On the other hand, it uses sophisticated risk analysis methods to demonstrate the good safety record of most currently used nuclear reactors. Reactor accident probabilities depend a lot on the reactor type considered, as well as the safety culture under which reactors are operated. Soviet type RBMK reactors are more likely to experience a serious accident than conventional PWR or BWR (collectively called LWR) reactors, and RBMK reactors were more easily subject to incidents under the Soviet safety culture of two decades ago than under that prevailing today in the Russian Federation. Evolutionary reactors, based on the PWR technology, and more revolutionary reactor designs, with e.g. a variety of so-called passive safety properties, are, on their turn, less subject to severe accidents than their conventional PWR predecessors.

\subsubsection{Incident probability and control of consequences}

Whereas the mix of reactor types considered and the safety procedures that are being applied determine to a large extent the likelihood for the occurrence of accidents, a simple calculation provides some feeling for the possible rate of the world experiencing reactor accidents in the future. Such a calculation can e.g. be based on the number of reactor accidents that have occurred since the beginning of the civil nuclear era and the amount of reactor-years that have been realised to date. Apart from some of the reactors designed in the former Soviet Union, particularly the Chernobyl-type RBMKs, the present generation of nuclear reactors has had a rather good safety record. In the rest of the world, some 10,000 reactor-years of commercial nuclear power operation experience have been obtained. This experience involved no accident with a large external release of radioactivity. One serious accident occurred with fuel melting: the accident at Three Mile Island (TMI) in 1979. These statistics indicate that the probability of an ac- 
cident with fuel damage is low. Without claiming full statistical soundness, one could make an argument that such probability lies perhaps around one in 10,000 per reactor-year (see also Sailor et al., 2000). This could correspond to a large external release of radioactivity, like in the case of the 1986 Chernobyl accident, every 100,000 reactor-years, since the chances hereto are considerably lower than fuel melting. Such a probabilistically feeble, but insightful, inspection of accident occurrences could indicate that with 400 reactors worldwide, the expectation would then be for a Chernobyl-scale nuclear accident to occur about every 250 years.

Hence, even for conventional reactors, seen from this perspective, the probability for experiencing a reactor accident is rather low. By common standards, however, this rate probably means that a continued, or perhaps even expanded, use of the actual nuclear park of 400 reactors provides insufficient and unacceptable safety guarantees for the future. One of the reasons is that the consequences of a serious accident, if it happens, can be large. The potentially pervasive scale of reactor meltdown accidents was experienced through the Chernobyl accident in 1986, which involved some 40 immediate deaths, and a radioactive contamination of vast areas surrounding the reactor. The environment will remain radioactively contaminated for very long periods of time. It is exceedingly difficult to calculate the number of victims from such an accident, both for statistical reasons, and since uncertainties exist among specialists regarding the model that ought to be employed to describe the effect on human health of low radiation exposure. If one assumes the Linear No-Threshold (LNT) model, many thousands of people are expected to get a fatal cancer as a result of the exposure to radiation from the material released in the Chernobyl accident. Since 1986, both regarding the probability for accidents to occur, and in terms of the control of potential consequences, a lot has changed.

\subsubsection{Safety improvements since the $1980 \mathrm{~s}$}

The Chernobyl accident has had a tremendous impact on the perception of the risks involved with nuclear energy, notably from the public. In the former USSR, many technical improvements have been realised since 1986, and a lot of effort has been put into increasing the safety and operation conditions surrounding nuclear power plants. Chances for Chernobyl-scale accidents to occur in the Soviet successor states have therefore, fortunately, become increasingly small. In addition to all sorts of improvements on the technologies and materials used for reactor operation, a confinement dome now equips basically all power plants. This confinement dome ascertains that, in the occurrence of an accident, the radioactive material is not released to the outside environment. Probably more importantly, since the Chernobyl accident the manmachine interactions in reactor operation have been considerably improved, especially in the former USSR. Special attention has been paid to the human factor in reactor operation, since one of the main causes for the Chernobyl accident to have happened was a series of human mistakes made when the safety mechanisms were deliberately switched off in order to perform a test. The Chernobyl operators had brought the reactor on purpose, prior to its meltdown, into a very special and unsafe condition.

Some ten RBMK reactors, by most considered to be ill designed, are today still being operated. In general, the safety conditions surrounding the Soviet nuclear heritage in Russia are often in a poor state. The likelihood of severe accidents to occur in the future (with 'severe' or 'serious' accident being meant an accident not necessarily of the scale of Chernobyl, but possibly implying a significant radioactive exposure of some level to the population neighbouring the nuclear power plant) has not been reduced to zero. Notwithstanding the safety improvement achieved over the past decades, and those expected and desired in the decades to come, various aspects of Russia's nuclear industry create conditions that are unfavourable for the development of nuclear energy worldwide.

Also in developed countries, in the aftermath of both the TMI and Chernobyl accidents, many improvements have been realised, both on a technical level, and regarding human and operational factors in power generation. One of the measures that has contributed to establishing a 
better safety culture is the putting forward of an international early notification system, involving the obligation to report any nuclear accident or incidents on the International Nuclear Event Scale (INES). This scale classifies nuclear events on a scale from 1 to 7 and helps national authorities in determining the possible consequences of nuclear accidents. The improvements achieved in reactors in industrialised countries have reduced the occurrence of serious accidents to perhaps a level of one per millennium, if a world of 400 reactors is assumed. Also in the industrialised world, however, consisting basically of those countries member to the Organisation for Economic Co-operation and Development (OECD), risks for serious accidents to occur are still unequal to zero.

Unfavourable for the creation of a safety image is the observation that small incidents, e.g. at the level 1 or 2 of INES, continue to occur regularly (see, for example, van der Zwaan, 1999). On the one hand, such incidents are worrying, and their occurrence constitutes an aspect that reinforces the sceptical attitude of the public towards nuclear energy. On the other hand, however, small incidents occur in all branches of industrial activity. In most other industries no international notification system exists, although the impact of their activities, e.g. in the chemical industry, can be large. The nuclear industry has become very sensitive for the occurrence of small incidents, even if they have negligible effects on human health and the environment. The INES scale has brought lots of transparency that the nuclear industry needs badly to improve its image of secrecy. Nevertheless, as long as similar standards are unknown or not used in other hazardous industries, the ultimate effect on public opinion may be adverse. The nuclear notification system might be considered exaggerated in comparison to practices as they occur in other industries, and might put nuclear dis-proportionally in bad light.

Scope exists for enhancing nuclear security and reactor safety. Combined research and development efforts, between all countries planning to continue the use of nuclear energy, can be undertaken to design reactor types that are safer than the presently used conventional PWRs. New designs for power plants exist already. They are considered safer than current plants for a number of reasons. First, because they make greater use of passive-safety features. Second, since they build on the construction and operation experience gained in today's plants. A number of these designs promise improved safety levels for the future. These include the US designed Advanced Boiling Water Reactor (ABWR) and AP-600 reactor, the French-German EPR pressurised-water reactor and the Canadian CANDU-9 heavy-water reactor.

Two ABWR plants are now in operation in Japan, and two others are under construction in Taiwan. The Canadian and US reactor designs have been offered on a commercial basis for several projects in East Asia. The French-German EPR is undergoing a detailed licensing process. In parallel with the commercialisation of these designs, a continuing (still relatively small-scale) effort is under way to design a new generation of advanced reactors not based on extensions of the current light- (or heavy-) water reactor technology. These reactors may prove to have various beneficent characteristics, one of which is their 'passive' safety property. Passive, or inherent, safety means that physical laws ensure that reactor excursions or meltdowns are entirely excluded. While incidents with small amounts of radioactive emissions could perhaps still be allowed for, some argue that such passive safety constitutes a sine-qua-non for the sustainability of nuclear energy. It seems that inherently safe reactors can in principle be designed. An example of such a reactor is the helium-cooled modular High Temperature Reactor (HTR, also called HTGR for High Temperature Gas-cooled Reactor, or PBMR for Pebble Bed Modular Reactor), currently contemplated by a number of countries, among which South Africa. Since such reactors provide opportunities for establishing intrinsic reactor safety, they deserve enhanced attention.

If there is a future for nuclear energy, then it will be crucial to establish high and augmenting safety levels, both in countries that possess nuclear energy and in those that plan to acquire it in the future. The IAEA should continue, and perhaps enhance, its role in providing safety criteria and securing optimal operational practices everywhere in the world. This is especially the case 
in Russia, where still a number of relatively unsafe RBMK reactors are kept running, and in those countries in Asia that are likely to progressively employ more fission for their increasing electricity needs and where operation experience needs to be developed. Particularly in countries where lots of space is available, such as China and Russia, special consideration could be paid to selecting sites for those new nuclear power plants that do not yet possess full passive safety properties, like currently used PWR reactors. However safely they can be designed today, it might be appropriate to situate them mainly in areas where they are likely to cause limited damage to the local population, in the rare event of a serious accident, since accident risks remain non-zero for these PWR reactors. Because of its inherent safety properties, like those of some other new reactor designs, the HTR might be fit for being built in populated regions, e.g. around coastal zones in South Africa, or close to mega-cities in China or India.

\subsection{Nuclear proliferation}

The civil use of nuclear energy inherently involves threats regarding the possible non-civil diversion of the technologies involved as well as the materials produced in the nuclear industry. Among nuclear energy's main dangers in terms of proliferation is, on the one hand, the use of enrichment facilities and, on the other hand, the production of fissile materials, during reactor operation, that remain embedded in nuclear waste.

\subsubsection{Sources of proliferation}

For nuclear power production, facilities are needed to enrich natural uranium, containing about $0.7 \%$ of fissile uranium-235, up to levels of $3-4 \%$ of this isotope. Whereas these enrichment $\mathrm{fa}$ cilities cannot be readily employed for enriching to much higher levels of uranium-235 (the facilities would need to be transformed significantly for this purpose), to obtain highly enriched uranium (HEU), the enrichment technologies required for attaining such high levels are the same as for low enriched uranium (LEU) production. HEU can be employed for the fabrication of atomic explosives. The availability of enrichment technologies poses risks for nuclear proliferation, especially in countries considered to be rogue states that have interest for using these technologies for military purposes. In places where HEU is available for military purposes, threats exist that terrorists get access to this material. If nuclear energy were expanded in the future, enrichment facilities might be constructed in many different locations around the world, including the Far East and South. Safeguarding the facilities will then become more challenging.

More than 50 ton of plutonium per year is produced by the current nuclear capacity of over 400 reactors. Most of the plutonium isotopes contained in spent reactor fuel are fissile. This plutonium can therefore, in principle, be used to construct nuclear devices. This poses serious problems for nuclear non-proliferation regimes, and necessitates dedicated technical and institutional safeguarding efforts. Especially in the context of spent fuel reprocessing, these problems become apparent.

\subsubsection{The issue of reprocessing}

Whereas plutonium in the spent fuel standard is reasonably safe against diversion for weapons use - because of the highly radioactive materials in which it is embedded - its separation in a reprocessing economy requires proper safeguarding to avoid it being diverted for non-civil purposes. Since reprocessing involves the separation of plutonium, it is considered to enhance the risk of nuclear proliferation. Plutonium produced in civil power reactors is less suitable for the production of explosive devices than weapon-grade plutonium. This is partly because it consists of a less advantageous isotopic composition, and produces heat, rendering the fabrication of a bomb more intricate. It has clearly been established, however, to be useable for building powerful nuclear weapons. The countries that reprocess spent fuel employ high standards of safe- 
guarding their separated plutonium, as prescribed by the international community. Nevertheless, establishing a reprocessing economy is considered to enhance the risks for international security, e.g. as a result of possible failures in the accounting of materials. Still, even without reprocessing, the proliferation risks of nuclear energy are large.

It is argued, notably in the US, that reprocessing involves unnecessary threats to proliferation regimes, and ought therefore to be discontinued. One of the arguments is that uranium resources are large enough to obviate the need for reprocessing for a long time, even when nuclear energy were to be massively expanded. Nevertheless, if nuclear energy is to be continued, a gradual future depletion of exploitable and economically viable uranium reserves will in the future undoubtedly revive the controversy over whether or not to reprocess and establish a plutonium economy, irrespective of its somewhat higher costs. Another element in the discussion is that the existing stockpiles of fissile materials, largely from dismantled warheads, are very large. These materials can be used in the civil power industry. On the one hand, such use of military materials would provide another reason for obliterating reprocessing. On the other hand, the continued use of nuclear energy can serve another purpose than generating electricity: it can help purging legacies from the Cold War, that is, the enormous stocks of uranium and plutonium still kept in the US and the former USSR.

\subsubsection{Innovations to avoid proliferation}

Research and development ought to be promoted to design reactors that are less prone to proliferation of nuclear weapons. Potential for the development of such reactors is available. In fact, already today reactors exist that have relatively advantageous non-proliferation characteristics. An example is the Canadian CANDU reactor, which does not need enriched uranium as fuel, but natural uranium instead. New reactor designs are being proposed, e.g. based on the use of thorium as fuel, that have the potential of reducing proliferation risks considerably. One of the reasons is that some of the new designs employ less plutonium, or avoid its use altogether. Other designs make access to fissile materials more difficult.

However advantageous in some proliferation respects, the thorium fuel cycle poses, like the uranium fuel cycle, severe proliferation problems of its own. Recently proposed acceleratordriven reactor systems, although being in a very initial state of research and still requiring radically innovative advancements in a variety of their technological composites, could alleviate the fissile material problem considerably. They seem to possess the potential to incinerate or transmute this material, as well as minor actinides and fission products generated through nuclear power production and embedded in radioactive waste (from which, hereto, they need in principle be separated). Also with these highly revolutionary models, however, the risks for nuclear proliferation will never become zero. All nuclear reactors, however newly designed and incorporating whatever progressive proliferation-beneficent techniques, pose proliferation risks. It would be erroneous to assume that totally proliferation-resistant reactors can ever be built.

\subsubsection{Institutional issues}

Nevertheless, civil nuclear energy has played only a moderate role in the acquisition of nuclear weapons by some states. Only a few states (notably India, Israel and Pakistan) have developed nuclear weapons somewhat aided by the use of research reactors obtained under the guise of peaceful nuclear programs. The five official nuclear weapon states have all acquired their nuclear arsenal by first developing dedicated military technology. Only afterwards, they have started to deploy the obtained expertise for applications in the field of civil nuclear power generation. The most convenient way for a country to develop nuclear weapons, if it desires to do so, is to build special reactors designed for specific military purposes. Developing nuclear weapons via the civil route is considered both more tedious and time consuming. 
Proliferation risks will always remain, not just because all existing reactor types pose proliferation risks, but also because no fully proliferation-resistant reactors can be designed. It is important to add, however, that these risks will remain, even if nuclear power ceased to exist. If the civil use of nuclear energy were phased out, the direct path to obtain nuclear weapons - although perhaps somewhat less easy to follow - would still remain largely open. Also the use of radioactive sources in many other domains, such as in medicine, renders the fabrication of radiological weapons (not based on fissile materials, but on the dispersion of highly radioactive materials) still very feasible.

The above is the main rationale why institutions that guarantee the civil use only of nuclear technologies are so important. Improving international safeguards and institutions should have high priority, whatever the future share of nuclear energy in power production. The International Atomic Energy Agency (IAEA) should become influential enough and possess sufficient financial means to ascertain that nuclear technologies are not used for military purposes and to preclude that the present group of $5+2$ de facto nuclear weapons states (China, France, Russia, UK, USA + India and Pakistan) becomes larger. To this purpose, it should be in charge of an enlarged international safeguarding system and be in charge of refined bookkeeping of an as large as possible range of radioactive sources, fissionable materials and nuclear equipment world-wide.

\subsection{Economic competitiveness and market performance}

In a number of (admittedly, perhaps rather special) conditions, nuclear energy has proved to be able to compete well with its fossil alternatives. A good example is the case of France. However, seen from a global perspective it has not done so in a very convincing way. As a matter of fact, at present the economics of nuclear power is likely to become increasingly less favourable. Some of the reasons for this have to do with the economic risks to be taken by investors as a result of economic and judicial uncertainties regarding nuclear waste and reactor accidents. The main economic problematique is probably related, however, to the capital intensity of nuclear power capacity construction and unfortunate cost structure vis-à-vis the current situation of market liberalisation. In terms of negative externalities, on the contrary, opportunities might emerge for nuclear energy in the future.

\subsubsection{Current situation}

In the current context of liberalisation of the electricity and energy market, nuclear's capital intensity constitutes a clear disadvantage. Initial hopes that economies of scale could bring about significant cost reductions for nuclear energy have never been realised, partly as a result of the increasing costs required for guaranteeing reactor safety, radiation protection and waste disposal. The claim of some nuclear technologists in the 1960s that nuclear energy could eventually become very cheap has proved to be unrealistic. Overall, the economics of nuclear energy appear today rather austere, in particular for newly constructed power plants.

In those places where gas supply infrastructures are in place, new nuclear power plants cannot compete against natural gas-fuelled combined cycle gas technologies (CCGTs) at current and expected gas prices (see, for example, IPCC, 2001). In particular if coal has to be transported over long distances or natural gas infrastructures are not in place, however, nuclear power can be competitive against coal and natural gas. Nuclear energy has generally relatively low fuel, operation and maintenance costs, and many of the currently deployed nuclear power plants are already fully depreciated. Therefore, the majority of the nuclear reactors worldwide today are competitive on a marginal cost basis in a deregulated environment. Especially advantageous in this respect is the fact that, over the past two decades, reactor operation availability has become high. Extending the lifetime of reactors, whose investments have been largely paid off, is cur- 
rently attractive, since they provide electricity costs that compete well with all of the present alternatives to nuclear energy.

\subsubsection{Cost structure, liberalisation and interest rates}

One of the main problems nuclear energy faces in this liberalisation environment is its high capital intensity, in comparison to other energy resources. For nuclear energy it takes considerably more time to write off the large up-front investments than for example in the case of natural gas power plants. Especially in a liberalised energy market, this aspect disadvantages increasingly decision making concerning the construction of nuclear power plants. Today, nuclear power plant construction costs some 3-4 times more than an equivalent capacity conventional power plant based on fossil fuels. If nuclear is to gain in economic competitiveness, especially in an increasingly competitive environment, efforts should be undertaken to reduce the investments required for plant construction. Some state that significant cost reductions can be achieved, but overall it seems difficult to judge whether overall investment costs can be reduced so as to render nuclear energy more favourable with respect to fossil fuelled power plants.

In much theoretical economic analyses, especially regarding environmental problems that stretch over long periods of time - such as global warming - the discount factor determines to a large extent the nature of policy conclusions. The discount factor, or pure time preference factor, is directly related to the interest rate employed in economic models. Many economists suggest that historic data or 'real life' interest rates should be used in economic analysis. This implies that a relatively high value for the discount rate ought to be used. Some oppose this descriptive view, and argue for a prescriptive approach in which one uses low discount rates. This allows future generations not to be discriminated, and allows more readily for resource conservation and protection of the environment. The right attitude towards discounting is an ongoing item in the sustainability debate.

The value of the prevailing interest rate determines to a large extent whether nuclear energy is considered competitive or not. With high interest rates, e.g. 10\%, reflecting for example a liberalised energy market, nuclear energy (like, as a matter of fact, e.g. large hydro-electric dam projects) is put into disadvantage, and will likely possess difficulties to compete with less capital intensive alternatives. It is especially this capital intensity that creates difficulties in a liberalised economy, since investors are less inclined to take capital-intensive long-term risks in a liberalised environment. This is related to a number of factors, among which a liberalised economy being characterised by relatively high discounting rates, shareholders demanding higher rates on investments, and utilities facing more uncertainty as to whether they can charge costs to their clients. An added problematique is that insurances that cover nuclear's long-term risks are often dependent on guarantees from national governments. With low interest rates, nuclear energy's economic position is more favourable, and could in many cases compete successfully with fossil fuel based energy resources.

The reverse side of this argument can be made in view of some long-term environmental problems. Especially when climate change problems are studied, many argue that low discount rates should be employed, in order to control it within acceptable levels. Low discount rates are employed in parallel with low interest rates. With such low interest rates, nuclear energy seems to possess certain advantages, since it becomes competitive with such interest rates, while not emitting carbon dioxide. On the other hand, the matter becomes rather complex if one considers both global warming and nuclear waste simultaneously. If low discounting factors are used in order to guarantee limited increases of the global average atmospheric temperature, and nuclear energy is thereby brought into relative advantage, then the burden left to future generation by the production now of nuclear waste weighs heavier, which disadvantages nuclear energy. 
During the 1980s and 1990s, nuclear reactors were built that were increasingly large. The capital investments required for these plants augmented accordingly, disfavouring nuclear energy in a market that is currently being liberalised. Today, installed capital costs for new nuclear power plants around the world range from $\$ 1,700$ to 3,100 / $\mathrm{kWe}$ (Paffenberger and Bertel, 1998). The current tendency to attempt curbing the fashion to build big plants, but construct small plants instead, might come to the rescue of nuclear power. A good example in case is the plan of the South-African utility ESKOM to build PBMR modules that are of the order of only $100 \mathrm{MWe}$, a capacity quite unlike the conventional 1000-1500 MWe for a single nuclear reactor. Depending on local demand conditions, nuclear power plants can be built that consist of a series of one to ten generating units of $100 \mathrm{MWe}$ each, for which costs are claimed that amount to only around $\$ 1,000 / \mathrm{kWe}$. The flexibility created by working with modules permits smaller initial capital investments, as well as shorter construction lead times. It could even create long-desired savings from series production of some standardised design.

\subsubsection{Market regulation and externalities}

At present, electricity production with natural gas-based technologies is more attractive than with nuclear power plants for a number of reasons. First, it is cheaper than nuclear energy in terms of overall electricity generation costs. Second, in addition to its overall more advantageous electricity production prices, it is economically more interesting for another reason: its costs structure is different, that is, its investment costs are considerably lower in comparison to those for nuclear power. This provides considerable flexibility as for the economic planning of power plant construction. Related hereto is the property of natural gas power plants that they are easily fabricated in relatively small modules. One of the main advantages of natural gas powered plants remains that efficiencies have been reached today that are high, while natural gas prices are currently low (that is, on average, since considerable geographic differences in gas prices occur world-wide).

Although there might be some scope for modest efficiency gains in conventional nuclear power generation, an overall significant cost-reduction trend is unlikely to exist for nuclear energy. If compared to fossil fuels nuclear energy is to improve its economic attractiveness, efficiency gains should be obtained in energy production, and up-front investments should be lowered. The former could be obtained e.g. via the co-generation of power and heat. The latter could be achieved, for example, by bringing down power plant construction costs, in particular by optimising the use of equipment and materials. It is uncertain, however, how large and how effective overall cost reductions for nuclear energy could be. It seems that the nuclear industry could gain a lot if it could be transformed from a construction industry, building grosso modo each time one reactor of a kind, into a manufacturing industry, where standardisation and the fabrication of 'prefab' parts become prevailing.

So far, for nuclear energy negative externalities have been more extensively included in electricity costs than in the case of its fossil-based counterparts. Spent fuel disposition costs are included in the nuclear fuel cycle, so that nuclear waste disposal is in principle accounted for in the electricity price. The internalisation of various environmental externalities of fossil-based energy resources, for example by means of taxes levied on carbon emissions or environmental pollution, has not yet been realised, and proves to be difficult, e.g. for reasons of international politics.

The proper internalisation of negative externalities for all energy resources could reinforce the competitiveness of nuclear energy. It is pointed out that on objective grounds of safety, total costs and comparative waste problems, nuclear energy can compete successfully with for example coal, since the external costs of the latter are relatively high (see e.g. Radetzki, 2000). Such statements might not be based on analyses that take fully into account such peculiarities of nuclear energy as nuclear proliferation. If all environmental externalities are internalised, proliferation should also be incorporated into the costs of electricity, but in externality calculations 
usually it is not. Still, for proliferation, the incorporation of costs related to elaborating nuclear materials safeguards, reactor safety control agencies and international surveillance institutions, capable of guaranteeing the civil use of nuclear energy only - however difficult to quantify could prove to be considerable. One could argue, however, that, since these costs need to be paid for anyway - that is, also in the absence of civil nuclear energy - they need not be accounted for as an economic externality. One could also question whether the funds currently reserved by utilities to dispose permanently of nuclear waste are sufficient. For example, if longterm recoverable waste storage were to be chosen as disposition option, site supervision costs would need to be accounted for. Such would perhaps even need to be accounted for if definitive underground storage were opted for, e.g. to avoid people unknowingly or voluntarily starting to dig at some storage location. It is unclear to what extent current electricity prices reflect such future costs; it seems difficult to incorporate them in external cost calculations. Note that costs related to potential large reactor accidents are in principle not included in present electricity prices, but that they are accounted for in external cost calculations (see, for example, ExternE, 1995). The costs of accidents can be high, but since their occurrence is low, reactor accident costs do not contribute perceptibly to total (internal plus external) electricity production costs.

\subsection{Energy resources, reserves and prices}

A property that remains in favour of nuclear energy is its small dependence on the costs and availability of fuel. Fuel prices and availability are two variables that are intimately linked. Nuclear energy costs are only to moderate extent dependent on fuel prices because of the particular cost structure of nuclear energy (see, for example, WEA, 2001). They are only remotely dependent on the availability of energy resources, since, in volume, so little energy providing material is needed to generate electricity.

This property of nuclear energy is much unlike its fossil-fuelled counterparts. The competitiveness of natural gas is today partly a result of the current low natural gas fuel prices. It seems that large increases in the spot price of natural gas could reduce significantly the attractiveness of natural gas plants with respect to nuclear power plants. Energy security was one of the main reasons France chose to develop a vast nuclear energy program in the 1970s. Also for the future, criteria regarding energy dependence will continue to play a role in political decisions concerning the choice between energy options. In terms of energy resource security, nuclear energy seems to possess a certain value, which is often neglected in economic analyses.

At present, uranium resources seem to be abundant, and no scarcity is likely to occur in the near or medium-term future. A long-term use, or possible expansion, of nuclear energy, however, would require a thorough assessment of the availability of sufficient uranium resources. Currently known and exploitable reserves can supply uranium for another 50 to 100 years, at the present rate of consumption. New, exploitable uranium mining sites are still likely to be discovered, extending the availability of fuel for power generation. At current low uranium prices, however, the scope of such discoveries is not expected to increase the available reserves by an order of magnitude. Perhaps they could, but it would be at a significantly higher price. Therefore, the possibility to gain uranium from less economically viable mines and less appropriate uranium ores, or recovering uranium from seawater, needs at some point to be investigated. Meanwhile, it would seem useful to further explore the opportunities offered by using thorium as fertile material. Thorium is supposed to be more widely available in the Earth's crust than uranium, more abundant by about a factor of three to four probably. In fact, India - planning seriously a significant expansion of its civil nuclear power programme - is expected to possess large resources of thorium, and therefore is one of the countries interested in exploring further the opportunities the use of thorium could provide. 


\subsection{The role of public opinion}

Another factor, which is of utmost importance in considering nuclear energy, is public opinion. Today, public opinion determines to a significant extent, in mature democracies at least, what kinds of energy resources are chosen by governments. The public is, by and large, rather sceptical apropos nuclear energy. Given its numerous problems, this scepticism is not surprising and in many respects justified. Whether fully rational or not, public common sense is a primordial determinant of future energy systems choices, which cannot be captured by economic modelling, and in relation to which economic analysis can even become meaningless.

\subsubsection{National nuclear energy programmes}

The level of scepticism is not as profound in all countries, but overall, even while fossil fuels are discredited today as a result of their harmful climate change and environmental pollution effects, nuclear energy ranks low in positive public opinion. The disadvantages listed earlier are largely of a technical, economic or institutional nature, and considered by some scientists and policy-makers as solvable - albeit serious - problems. For addressing the negative public attitude towards nuclear energy, no clear recipe exists. In any scenario where nuclear energy is to play a significant role, public perception should be rendered more positive. For the moment, public opinion on nuclear energy seems unlikely to significantly alter in the near future. It is not excluded that an intensification of extreme climate events as a result of global warming will put fission in a new perspective. The public opinion towards nuclear in emerging economies such as China and India will be very important to what will actually happen to nuclear energy, because it is in these countries that most of the world energy's expansion will occur.

In the US, public acceptance is a serious obstruction to enhanced use of nuclear energy. Sweden is, in principle, committed by public referendum held in the 1980s to gradually phase out nuclear-powered electricity generation. Largely as a result of anti-nuclear sentiments in the population, the German socialist-green coalition government has now set a fixed time schedule to definitely abandon nuclear energy. The Netherlands possesses only some $4 \%$ of electricity produced by nuclear energy, and is officially planning to phase out nuclear energy in a couple of years. The main rationale for the Dutch government to abandon nuclear energy is the absence of support of the Dutch, some years ago, to keep the nuclear option open. The Dutch today seem to be partly opposed to rather indifferent towards the nuclear energy option. Notwithstanding the critique the French nuclear industry is continuously receiving on a number of fronts, in France the public's sentiments are generally rather favourable towards nuclear energy, perhaps explainable by the large share of nuclear energy ( $80 \%$ of its electricity production is produced by fission) in its national electricity supply.

In most developing countries, issues of public opinion do as of yet not play major roles in national decision making vis-à-vis energy equipment investments. In these countries the predominant factor today is the mere level of these investments. In this respect, nuclear energy is clearly in disadvantage, since in countries such as China and India the availability of cheap coal makes the chance rather small that their currently modest capabilities of capital-intensive nuclear power can be expanded beyond a few percent in the near future. But this observation might change in the future, in two ways. First, as these countries develop, and higher levels of welfare are attained, more opportunities arise to invest in more capital-intensive programmes. Second, when consumption and welfare levels of the population rise, the role of its opinion towards governmental policies, in particular regarding choices in the energy field, might increase. Changes of this nature, however, are not likely to occur for at least some decades to come. 


\subsubsection{The critical West, apathetic East and awakening South}

We end this section by summarising the situation, in particular in terms of public opinion, of nuclear energy in three major global regions, characterised as the West, the East and the South. If the attitude towards nuclear in the West were to be typified by one word, notably vis-à-vis the perception by the public of nuclear waste, accidents and proliferation, 'critical' or 'hesitant' would probably be the most appropriate. Clear decisions to abandon nuclear energy, definitely in the short term, have so far only been put forward in rather exceptional cases. No plans for expansion or the construction of a significant number of new reactors have recently been proffered either. Rather, nuclear power production in the West seems to be in a kind of status quo, hesitant with respect to abandoning the present situation of stagnation.

As a result of as of yet often unsatisfying safety conditions and some security risks involved with the nuclear inheritance of the ex-USSR, 'apathetic' or 'tired' would probably qualify the nuclear situation in Russia. Its desire to continue employing nuclear energy, however, seems rather firm. But the past and present safety record makes many specialists doubt whether nuclear energy can be used in a responsible enough fashion. The attitude towards a number of issues concerning nuclear security is still often below the required level in the West, and national authorities should increase their role in providing a sufficient safety culture. Progress needs to be made in this field, and the apathetic ambience turned into a pro-active one. Part of the Russian public has justified doubts on nuclear's future in Russia, fed by e.g. the Chernobyl accident and the numerous neglected waste sites everywhere in the country. But national proud regarding Russia's vast scientific expertise in the field will importantly contribute to a continued, and possibly expanded, use of nuclear energy in the future. Through technology transfers and (operation) safety experience exchange to countries of the former USSR, as well as countries of Central and Eastern Europe, the West can contribute to guiding their nuclear future in safer and less apathetic paths. Given the possibly large-scale geographic effects of serious accidents in the East, West-European countries (the EU) can also benefit themselves from such a participating stance.

As with the economy as a whole in many countries in the Far East and South, 'awakening' or 'initiating' seems to suit nuclear energy's future rather well. It is in countries like China and India that most of the world's expected energy consumption increase is to be expected. Many countries in the Southeast, including e.g. South Korea and Japan, have therefore serious plans to expand their nuclear power capacity. It is interesting to see that the strategies employed by these South-eastern countries vis-à-vis nuclear energy can vary widely. Whereas some of them choose to base their power system on one main nuclear technology, which subsequently is developed on a large scale, such as in Japan, China for example has deliberately chosen to start developing various reactors of different types simultaneously, so as to keep its options as open as possible while waiting for the most convenient technology to emerge. The reactor and operation safety adhered to will be crucial elements to be considered by local governments in all countries in the Southeast. Opportunities exist in this region of the world to make a fresh start in terms of establishing high levels of safety standards surrounding future nuclear power plants. Many countries in the East are expected to establish high safety levels of themselves, but the West (collectively referring to commercial firms, national companies and institutions in the West, as well as organisations such as the IAEA) can still play an important role in transferring their acquired technologies and (operation) experience. Companies can even consolidate their commercial activities, especially those for which insufficient opportunities exist at present in the West. Public opinion plays as of yet little role in these countries. When an acceptable safety culture can be established, perhaps public opinion will not gain the negative impetus there as it has done so over the past decades in the West. 


\section{GENERIC RISK COMPARISON BETWEEN NUCLEAR AND COMPETING ENERGY RESOURCES}

\subsection{Risk management along sustainable energy paths}

\subsubsection{The importance of risk management for sustainability strategies}

Risks concern the threat of major negative consequences that are subject to basic uncertainty. We will use the term risk here in this qualitative sense, for when considering the risks of energy technology choices along sustainable energy paths it is often very difficult to attach precise quantitative values to impacts and probabilities as would be necessary for formal risk analysis. Moreover, the risks discussed can not easily be compared using a common denominator such as money or lives. Nevertheless, the issue of risks is crucial when comparing nuclear with competing energy sources, because like nuclear, competing energy sources also carry major risks although often of a very different nature. Sustainable energy paths will always be less than perfect in one way or another. On a very basic level, they involve the simultaneous solution of three fundamental questions: how cheap is cheap enough (particularly for renewable options), how clean is clean enough (particularly for fossil fuel options) and how safe is safe enough (particularly for nuclear options). There is a trade-off between economic risks, environmental risks and social risks. In the nuclear case for instance improved safety standards have led to substantial cost escalation and disappointing economic performance. These trade-offs are made even more difficult because the underlying technical and economic parameters such as conversion efficiencies, fuel prices and investment costs are continuously changing. The optimum path is dynamic and dependent upon the results of progressive institutional and technological learning, and can not be decided upon by once-and-for-all scientific calculation.

\subsubsection{An overview of generic risks}

Clearly, this is not the place to evaluate all risks of all energy sources exhaustively and quantitatively. Since a major message of the paper concerns the opinion, that the nuclear option can not be evaluated meaningfully in isolation from other energy-related risks, we will only briefly summarise the risks of other sources qualitatively. Three categories of risks are used corresponding to the three dimensions of sustainable development: the economic dimension, the environmental dimension and the social dimension. These long-term risks have so far played a modest role in the public discourse on energy future. According to the Netherlands Scientific Council for Government Policy such long-term risks are fundamental to social choices on sustainable development and by their very nature normative in character (WRR, 1995). From the point of view of global energy risk management and national policy decisions about nuclear energy, explicit consideration of the risks of fossil and renewable resources, in relation to nuclear risks, is necessary.

\subsection{Economic risks}

\subsubsection{Market performance}

Regardless of their environmental performance energy sources must still prove their competitive performance in the market place in order not to jeopardise the preconditions for economic growth. Although fiscal measures can help to penalise energy technologies with high external costs, it will not shelter energy technologies with low external costs from competition in an absolute sense, particularly not in a world that is increasingly dependent on market institutions 
rather than governmental regulation. Energy options all carry economic risks. For nuclear and renewable options, these have to do with high capital costs that make them less attractive in the market place where immediate and high returns on equity are the norm. For fossil fuel options, these have to do with high fuel costs that are subject to substantial fluctuations. To be sure, these types of risks can be difficult to measure in terms of standard risk analysis, which is usually based on low probability physical events with catastrophic and direct impacts on human welfare. Ultimately, a dismal economic performance however is as sure a road to ecological disaster and poor national health as catastrophic accidents. In terms of risk management it is well worth the effort to avoid long-run exposure to high cost resources, that show little improvement in market performance over time.

\subsubsection{Energy supply security}

The recent volatility in oil prices has refocused attention on the long-term dependence on imported fossil fuels of industrialised countries. It is no surprise therefore that energy supply security has reappeared on the political agenda of the USA and the EU. Recent statements by the American government about the deteriorating situation on domestic oil and gas markets and a green paper issued by the European Commission are symptomatic in this respect (CEC, 2000). According to the EU by 2030 Europe will depend for $70 \%$ on imported resources (presently $50 \%$ down from $60 \%$ in the early seventies). This makes the EU extremely vulnerable to supply disruptions and price instabilities, particularly since imports are increasingly from countries with a less than reassuring long-term stability record. Policies are needed to diversify the supply of energy across different energy carriers and across different geographical origins. The fact that the role of nuclear energy is declining in most member countries is viewed as aggravating the situation. The EU refrains from criticising these decisions of member countries but clearly recommends an open debate about the future of the nuclear option and underlines the importance of further research to solve problems of nuclear waste and safety. Nuclear energy is indeed inherently less subject to supply security issues than fossil fuels both with respect to price volatility and supply disruptions. From the point of view of economic stability and political autonomy this is an important consideration. Of course, this is also the case for domestically available renewable energy sources.

\subsubsection{Resource availability}

Whether the issue of resource availability is essentially an economic or a physical constraint, remains a matter of personal judgement. Recent key publications on sustainable energy futures based on joint efforts of many experts generally take an economic stance (Third Assessment Report of the IPCC and the World Energy Assessment of UNDP/UNDESA/WEC). They consider the impact of physical limitations in the period up to 2020 as relatively unimportant and even for the long term the major bottleneck will primarily concern the economic and environmental costs of unconventional resources rather than physical availability. An overview of present resource availability can be found in Table 3.1. The issue of resource availability thus becomes either a matter of supply security or of price escalation. Clearly, some fossil fuel resources are likely to reach substantial thresholds in exploitation costs earlier than others. The resource situation with respect to nuclear fuels on the other hand is strongly dependent upon the type of nuclear cycle considered for the long run. Renewable energy sources can not be compared meaningfully with either fossil or nuclear fuels because land use constraints pose essentially different risks (mainly because of competing uses and biodiversity impacts). 
Table 3.1 Summary of global fossil and fissile resources (thousands of exajoules)

\begin{tabular}{|c|c|c|c|c|c|c|}
\hline Resource & $\begin{array}{l}\text { Consumed by } \\
\text { End } 1998\end{array}$ & $\begin{array}{l}\text { Consumed } \\
\text { in } 1998\end{array}$ & Reserves & Resources & s Resource base & $\begin{array}{l}\text { Additional } \\
\text { occurrences }\end{array}$ \\
\hline Oil & 5.14 & 0.14 & 11.11 & 21.31 & 32.42 & 45 \\
\hline Conventional & 4.85 & 0.13 & 6.00 & 6.07 & 12.08 & \\
\hline Unconventional & 0.29 & 0.01 & 5.11 & 15.24 & 20.35 & 45 \\
\hline Gas & 2.38 & 0.08 & 14.88 & 34.93 & 49.81 & 930 \\
\hline Conventional & 2.35 & 0.08 & 5.45 & 11.11 & 16.57 & \\
\hline Unconventional & 0.03 & 0.00 & 9.42 & 23.81 & 33.24 & 930 \\
\hline Coal & 5.99 & 0.09 & 20.67 & 179.00 & 199.67 & \\
\hline Fossil total & 13.51 & 0.32 & 46.66 & 235.24 & 281.89 & 975 \\
\hline \multicolumn{7}{|l|}{ Uranium } \\
\hline Open cycle in thermal reactors ${ }^{\mathrm{b}}$ & n.e. & 0.04 & 1.89 & 3.52 & 5.41 & $7.1^{\mathrm{c}}$ \\
\hline Closed cycle with fast reactors ${ }^{\mathrm{d}}$ & - & - & 113 & 211 & 325 & $426^{\mathrm{b}}$ \\
\hline Fossil and fissile total ${ }^{\mathrm{e}}$ & n.e. & 0.36 & 48 & 446 & 575 & 1,400 \\
\hline
\end{tabular}

n.e. Not estimated.- Negligible

a. Sum of reserves and resources.

b. Calculated from the amount in tonnes of uranium, assuming 1 tonne=589 terajoules (IPCC, 1996a).

d. Calculated assuming a 60 -fold increase relative to the open cycle, with 1 tonne $=35,340$ terajoules.

c. Does not include uranium from seawater or other fissile materials.

Source: World Energy Assessment Report. Table 5.25.

\subsection{Environmental risks}

\subsubsection{Global climate change}

The Third Assessment Report of the Intergovernmental Panel on Climate Change (IPCC) is unequivocal with respect to the causes and consequences of human induced climate change. The risks of climate change are no longer considered an academic concern, but a physical reality. The consequences of continued fossil fuel use at a scale necessary to supply the major share of global energy demand in the first half of this century, will have grave and irreversible impacts unless substantial amounts of $\mathrm{CO}_{2}$ from fossil fuel combustion are captured and stored. Implementation of $\mathrm{CO}_{2}$ capture and storage however involves its own risks in terms of economic viability and retention safety. The characteristics of the different technological options available require extensive research efforts. The climate change issue could ultimately force environmental policy for fossil fuels from a dispersion strategy to one of containment such as has been the case for nuclear energy from the very beginning. But there the analogy ends, for nuclear waste products are extremely harmful in small quantities but very limited in volume, while fossil waste products are essentially harmless in small quantities but extremely voluminous. This makes the risks involved completely incomparable and containment strategies vastly different in their social and economic impacts. The political consequences and public preferences in this respect are far from clear and deserve much more attention by social scientists than is presently the case. For example, the public perception of underground storage of $\mathrm{CO}_{2}$ could, once developed, start showing certain analogies with the case of nuclear waste storage.

\subsubsection{Regional air pollution}

Regional air pollution from fossil fuel combustion remains a major environmental concern. Although the focus of attention has shifted somewhat from acidification problems related to $\mathrm{SO}_{2}$ and $\mathrm{NO}_{\mathrm{x}}$ to urban air pollution due to small particle emissions in the industrial west, in the developing south the problems of regional acidification are just becoming apparent. In addition to climate change these regional impacts impose substantial ecosystem threats that should be taken into account in any evaluation of sustainable energy paths. Reducing these risks may also interact with climate change strategies in unexpected ways, because complex atmospheric interactions between flue gases and water vapour may induce local cooling. 


\subsubsection{Local air pollution}

Local air pollution because of fuel combustion causes important health risks. These health risks are confined to inner cities in most developed countries, where they are relatively speaking, of low level impact. But in developing countries these risks are not only particularly severe, but manifest in both urban and rural areas. Indoor air pollution from cooking on traditional fuels (dung, wood, charcoal) has enormous health consequences, in particular for women and young children. In urban areas, the lack of pollution prevention in both mobile and stationary sources leads to very low outdoor air quality levels.

\subsubsection{Solid wastes}

The operation of nuclear reactors entails the production of radioactive wastes in the form of spent fuel, while the combustion of coal and biomass leads to substantial volumes of bottom and fly ash, which may contain toxic materials. Moreover, all technologies must be disposed off at the end of their life times. The case of nuclear wastes has been well documented both with respect to spent fuel and decommissioning of plants. Ash disposal is much less controversial. Experience with the problems of solid waste in the case of renewable technologies is very limited, but may grow in importance when reliance on renewable energy reaches a higher share of total supplies.

\subsubsection{Land use impacts}

The issue of land use impacts forms another area of emerging risks that are hard to evaluate quantitatively in the context of sustainable energy paths. The environmental or ecological footprint of different energy sources in terms of surface requirements and landscape impacts are widely divergent. The basic difference between the scale and character of impacts is clear, although the exact figures for specific technologies are bound to differ substantially depending on technological assumptions and local conditions. The footprint of biomass is the most impressive, not only in terms of affected surface area, but also in terms of biodiversity consequences, synergy with genetic modification and resource requirements (water, fertiliser). Competition with other uses, such as food and fibre production, is likely to arise when biomass feedstocks are used at a large scale. Wind energy and solar energy do much better. Under Dutch conditions the footprint of biomass electricity in terms of square kilometres is roughly 3 times more than that of a solar supplied neighbourhood, while the footprint of a windpark is 3 times less. Moreover, the latter two do not compete with other forms of land use in a way comparable to biomass, because they can use marginal lands or off-shore locations with limited economic potential and biodiversity vulnerability. Of course, while possessing more advantageous properties than biomass in terms of land use, solar and wind will remain constrained - even when installed in large capacities - by their intermittent nature. Land use requirements of fossil and nuclear technologies are substantially lower in terms of energy delivered per square kilometre. In fact, land use problems in these cases can be much more sensibly described in terms of specific ecosystem hazards, such as the consequences of oil spills or mining impacts, rather than in terms of surface areas affected during normal operation.

\subsubsection{Severe accidents}

The environmental risks so far discussed are associated with standard design operations of energy systems. Yet, in terms of public perception and scientific analysis, severe accidents are most commonly viewed as the major source of risk for energy systems. Nuclear and fossil fuels are both characterised by the occurrence of exceptional events with high impacts and low probabilities (coal mine disasters, oil spills, gas explosions, radiation exposures). Risk analysis is certainly an important tool to develop safe designs and evaluate risks rationally, but it can be a 
misleading tool for public choice. There may be a threshold level of consequence beyond which no accident is considered acceptable no matter how low the probability of occurrence. Disasters waiting to happen are to some degree as much a social risk as an environmental risk, because coping with disasters imposes substantial demands on technological preparedness, institutional stability and social coherence, that may be difficult to achieve in multicultural, market-oriented societies.

\subsection{Social risks}

\subsubsection{Technological infrastructure}

The impact of energy systems on society is not simply the sum of the environmental and economic impacts of individual systems. Some impacts transcend the separate contributions of different energy sources and are related to the complex technological infrastructure required to maintain and operate the system and ensure it's continuity. This infrastructure concerns not just the physical infrastructure related to transportation, distribution and storage of energy carriers, but also the human skills and institutions involved in the energy system. These impacts have to do on the one hand with the configuration of the total system at the macro level and on the other hand with the relation between the energy system and other branches of economic activity. The scale and distribution of energy production and use form one important aspect, because a highly decentralised infrastructure will necessitate a different type of technological infrastructure than a highly centralised one. Similarly, a society based on a highly diversified mix of resources will require a different mix of skills than a society reliant on a highly concentrated mix of resources. Such choices have different impacts on the vulnerability and flexibility of societies when faced with rapidly changing circumstances or extreme conditions.

To mention one example, renewable energy sources are often viewed as an ideal solution for solving problems of climate change. They are certainly very climate friendly. Unfortunately, they are not very climate safe. The performance of renewables tends to be more dependent on stable weather patterns, so if climate change becomes inescapable after all, investment in renewables will be systematically affected. Another example concerns the degree to which the desired skills have multiple uses. Perhaps biomass will never penetrate the energy market in any major way, but the skills developed in pursuing the biomass route could also be productively employed in replacing fossil by biomass feedstocks in the chemical industry.

Typically, this aspect of interconnectedness between dissimilar purposes has been and will remain a major issue for nuclear energy, where the borderline between civilian and military uses is thin and risks of weapons proliferation remain a major obstacle to peaceful uses of nuclear energy. On the other hand, nuclear technology plays a key role in medical applications necessitating a complex technological infrastructure regardless of other civilian or military applications. Although the task of evaluating these complex social risks of different types of technological infrastructure is difficult, these should occupy a central place in public choices regarding sustainable energy paths.

\subsubsection{Public opinion}

Because of the substantial external effects associated with energy technologies the role of public opinion plays a central role in decisions about sustainable energy paths. The past already has demonstrated the decisive influence of public opinion on energy sector choices in the case of nuclear energy. This influence is not likely to diminish in the future with the advent of liberalisation. In fact it may become a stronger force when government regulation reinforces public opinion through the creation of favourable market conditions for renewable energies and the penalisation of other energy sources. This will induce companies to follow explicit marketing policies in line with opportunities created by public decisions. Under such conditions public 
opinion simply reinforces itself through restrictive regulation of the market place. One of the major challenges of devising sustainable energy paths is to break through this potential vicious circle and establish an open and informed base for public discourse on energy choices. Recent developments in the Netherlands regarding public opinion on the merits of wind energy demonstrate the need for better communication policies and the risks of insufficient awareness of the complex issues involved in choosing for sustainable development paths. 


\section{CONCLUSIONS}

\subsection{The nuclear role in global sustainable energy paths}

\subsubsection{Important nuclear potential for transition period up to 2020}

Nuclear continues to play a central role in the construction of some global energy scenarios for the future. One important reason is the fact that nuclear energy already plays a substantial role in present electricity supplies, particularly in OECD countries. Globally, it contributes roughly $16 \%$ of total electricity consumption. In some OECD countries such as France and Belgium it is still the major supplier of electricity, in others such as the US, Japan, Germany and Great Britain it provides a substantial share. Although some countries have made a decision in principle on banishing nuclear from their future energy mix, few countries have taken any drastic action to implement this decision on a fast track course. In fact, improvements in nuclear operational performance and extensions in life-time of existing reactors combined with a lack of incentives for adding base-load from other sources, are prolonging nuclear's role far past the present decade.

A second consideration for including nuclear is based on the fact that there still remains a number of prominent OECD nations that continue to invest in a nuclear future regardless of the decidedly hesitant stance of most other OECD countries. Moreover, the position of many industrialising nations is far less pronounced with respect to nuclear policies than most OECD countries. Key countries like China and India that so far are heavily dependent on indigenous coal, are even mildly pro-nuclear, although under present economic and political conditions, they are not likely to concentrate power plant investments in the nuclear sector.

On the road to sustainability, there are many contenders for the ultimate sustainable blueprint, but there are few contenders for a prominent transitional role. The IPCC Third Assessment Report of Working Group III has quantified the potential transitional role of different energy technologies in terms of $\mathrm{CO}_{2}$ reduction potential up to the year 2020 and concluded that the potential role of nuclear comes out on top (Table 4.1). This is one important reason why global scenarios which aim at a sustainable energy path with substantial reduction of greenhouse gas emissions, are likely to include a nuclear scenario. In fact nuclear energy is already playing such a transitional role.

\subsubsection{Determinants of nuclear competitiveness after 2020}

The future role of nuclear will depend upon uncertain global developments that affect the competitive position of the nuclear industry. The degree to which government regulation will lead to internalisation of external costs of fossil fuels including climate change and supply security is the first important factor. In many respects this will improve the competitive position of nuclear. Large-scale introduction of $\mathrm{CO}_{2}$ taxes will penalise fossil fuel base load contenders and can easily turn the competitive balance, while it is not likely that renewable competitors will force nuclear off the market before 2020. Steps in this direction would require effective implementation of international climate change policies after the Kyoto budget period. This in turn depends on the direction and coherence of international policy ventures in the face of increasing evidence of major negative climate change impacts. Dramatic political developments in outside suppliers such as the Middle East and Russia might have similar consequences and evoke strong policy reactions in order to reduce supply insecurities and potential cost escalations. Such policies may favour the prospects for nuclear energy. 
The manner, in which the nuclear industry will be able to use its transitional role in the period up to 2020 to improve its cost performance, is a second factor. More specifically, the nuclear industry can presently be characterised as a construction industry in recession rather than a manufacturing industry in boom. The industry is too strongly dependent on one-of-a-kind site design and on-the-spot, large-scale construction. If it succeeds in sufficient standardisation, modular manufacturing of components and reduction of unit scale, it will be able to reap the benefits of mass manufacturing and lower initial investment costs much better. If not successful in improving its industrial performance during the decades to come, the chances for renewable sources to compete in the market place with nuclear will increase progressively, since renewable energy costs are likely to gradually decrease along their expected learning curves.

Finally, the evolution of positive public opinion on nuclear decisions in the industrialising nations of Asia and its impact on the persistence of negative public opinion in OECD countries could become a decisive factor. Attitudes towards nuclear power in Asia may differ substantially from those in Europe and the US for various reasons. First, this region is likely to face the most explosive growth of electricity demand and will be confronted with daunting challenges to expand capacity without aggravating air pollution at the local and regional level. Secondly, civil society plays a catalytic role in shaping and mobilising public opinion in democracies, but the strengths and concerns of civil society in many Asian countries differ substantially from those in Europe and the US. A positive attitude towards nuclear in Asia in the coming decades will reinforce the position of pro-nuclear OECD nations and assure survival of the ailing nuclear industry. Ultimately, this may weaken the position of anti-nuclear nations, particularly if they are not successful in achieving higher shares of renewables at an early stage.

Table 4.1 Estimated reduction potential(in MtC/y) of alternative mitigation technologies in the power generation sector compared to gas-fired CCGT power

\begin{tabular}{|c|c|c|c|c|c|c|c|}
\hline $\begin{array}{l}\text { Technology } \\
\text { Reduction potential } \\
{[\mathrm{MtC} / \mathrm{y}]}\end{array}$ & $\begin{array}{c}\text { CCGT } \\
\text { (baseline) }\end{array}$ & $\begin{array}{c}\mathrm{CCGT}+ \\
\mathrm{CO}_{2} \\
\text { capture }\end{array}$ & Nuclear & $\begin{array}{l}\text { PV and } \\
\text { thermal } \\
\text { solar }\end{array}$ & Hydro & Wind & BIGCC \\
\hline
\end{tabular}

Annex I Countries (industrial nations)

potential to 2010

potential to 2020

Non-Annex I countries (developing nations)

\begin{tabular}{llcccccc} 
potential to 2010 & - & 0 & 10 & 0.2 & 9 & 5 & 1 \\
potential to 2020 & - & $5-50$ & 70 & 4 & 26 & 21 & 6 \\
\hline
\end{tabular}

Source: IPCC-WG III Third Assessment Report, tables 3.35c and 3.35d , pp. 257-258.

\subsubsection{Nuclear energy as a global hedging option}

An evaluation of the risks attached to different energy technology choices is bound to change over time and between countries. Such evaluations will not only concern the relative level of risks for each major energy technology in relation to others but also the potential for controlling these risks with deliberate policies. The nuclear option is characterised on the one hand by its undeniable transitional role in the near future for at least a number of countries and on the other hand by concrete opportunities to reduce the substantial risks associated with its employment for at least the period after 2020. This sets it apart from technologies that are not in a position for a major near-term transitional role (such as renewable applications) or for which the longterm risks are less clearly defined (such as fossil fuel applications). These characteristics make the nuclear option a suitable candidate technology for hedging strategies, in which countries are willing on the one hand to endure the present risks of nuclear energy while at the same time investing in opportunities for preventing a continuation of their risk exposure in the future. 
Nations are bound to evaluate their options differently depending on local economic conditions and resource availability. It is unlikely that the wealthy industrial nations that are presently highly dependent on imported oil and gas will make similar choices as the poor industrialising nations in which coal and traditional biomass play a major role. This essentially implies that nations will make different portfolio choices in which they simultaneously choose for a certain mix of energy technologies with definite risks attached to be employed now and a certain mix of research and development options that will affect the severity of such risks in the future. If nations base their portfolio choice on hedging strategies, then nuclear energy is bound to play a role - certainly in the short run, possibly only temporary, but potentially also in the long run in establishing sustainable energy paths.

\subsection{Scenarios for nuclear energy policy in the Netherlands}

\subsubsection{The scenario of bottom-line retreat}

The planned closure of the one remaining Dutch nuclear power plant in Borssele is sometimes viewed as the end of the Dutch nuclear venture. This can be a misleading assessment in more than one sense. The bottom-line for nuclear energy policy in the Netherlands is not just a matter of closing domestic power plants and solving their legacy of radioactive waste. First of all, two more substantial nuclear installations remain in the Netherlands and their operation carries considerable weight in terms of international impacts. NRG in Petten produces the majority of isotopes for diagnostic, therapeutic and palliative use in European hospitals, while URENCO in Almelo supplies an important share of the global uranium enrichment market. These are essentially commercial activities, but their existence allows substantial economies of scale in providing and financing a bottom-line knowledge infrastructure that can also address inescapable public policy problems in the area of radioactive wastes and natural radiation. The future role of these nuclear technology services must remain a concern of public policy even after the closure of Borssele. Secondly, it is likely that the liberalisation of the European energy market will lead to systems of electricity labelling involving not only renewable energy but also nuclear energy. Some international suppliers active on the Dutch electricity market may even consider promoting something like a 'silver label' for nuclear among Dutch customers that are either decidedly pro-nuclear or interested in low base-load prices. Public opinion in general is not a good indicator of anonymous buyer behaviour. The imports of nuclear electricity may actually exceed the domestic supply from Borssele by the time of its closure. Nuclear policy questions may thus shift from traditional national supply concerns to international demand-side issues. In an integrated European context the issues of remaining nuclear installations and domestic nuclear energy demand form two additional elements defining a bottom line scenario next to problems of nuclear waste management and natural radiation.

\subsubsection{The scenario of cautious standstill}

It becomes increasingly apparent that the Netherlands will face serious implementation problems in fulfilling its Kyoto obligations. This is not only true with respect to its domestic goals, but particularly so with respect to its intended commitments abroad. Keeping the Borssele nuclear plant open well past 2010 would certainly help to smoothen the transition path towards a higher domestic share of renewable energy or clean fossil fuels. It would also prove a suitable hedging option against a slower take-off of CDM and JI projects than originally expected. Such a scenario of cautious standstill could also include the goal of maintaining a modicum of influence in setting the European nuclear policy and research agenda. Participation in European science and technology programmes, however, without a domestic knowledge base, is not likely to be very effective. Moreover, as we have indicated, there is substantial scope for technological developments that improve the performance of nuclear options from a sustainability perspective. The limited involvement of the Netherlands would serve two purposes: influencing the European research and policy agenda in a sustainable direction, and promoting involvement of Dutch 
researchers in particular niche areas of relevance for the Netherlands. This would lead to continuing involvement in research themes like life-time reduction and volume minimisation of high-level wastes, or the development of proliferation resistant fuel cycles. At present, such a cautious scenario is less likely than the bottom-line scenario, but this perspective may change over time, particularly if nuclear energy imports increase and global developments warrant a reconsideration of the nuclear option in an international perspective.

\subsubsection{The scenario of active involvement}

Although any decision to increase domestic nuclear research or expand domestic nuclear capacity in the Netherlands is highly unlikely for the time being, it is not inconceivable that public policy could be based along pro-active lines in the long run. At present, there is very little room for further debate on the nuclear issue. Bringing back the nuclear issue pro-actively on the political agenda carries small benefits and large risks. Environmental groups feel secure in their ultimate goal of phasing out nuclear and would be highly upset. Energy companies do not view nuclear plants as an appealing road to profits and would be disinterested. Energy policy makers have more urgent issues to worry about at present. Yet, there are circumstances that would make this comfortable quiescence increasingly difficult to maintain in the long run. Foremost among such developments would be a nuclear renaissance in the USA or Asia, in the coming decade, combined with diminishing prospects for clean fossil fuels and increasing concerns with security of supply in Europe. In such circumstances, a pro-active approach emphasising the need to improve the performance of nuclear energy on a fast-track course before opening opportunities for renewed investments, may gain political momentum, even in the Netherlands. A pro-active scenario of active involvement would not only include additional research funding for the various nuclear problem areas mentioned earlier. It would also involve renewed attention for a clearly outlined Dutch nuclear policy focusing on the position of nuclear energy in an integrated European electricity market. 


\section{REFERENCES}

ANS, 'Nuclear Power in the $21^{\text {st }}$ Century: Sixteen perspectives on the future of nuclear energy', Nuclear News, November 2000.

Beck P.W., Nuclear Energy in the Twenty-First Century: Examination of a Contentious Subject, Annual Review of Energy and the Environment, Volume 24, Palo Alto, 1999.

ECN Annual Report, 1998.

European Commission, Towards a European Strategy for the Security of Energy Supply, Brussels, 29 November 2000.

ExternE, Externalities of Energy, Vol. 1, Summary, European Commission, Brussels, 1995.

Gruppelaar, H., J.L. Kloosterman, R.J.M. Konings, Advanced Technologies for the Reduction of Nuclear Waste, ECN-R--98-008, ECN, 1998.

Hickey, Longmire and Longmire (Eds.), The Environment, Greenwood Press, 1994; therein: three chapters on nuclear energy by Hardy, Parmelee, and Tomain.

Hill, C., A.L. Mechelynck, G. Ripka and B.C.C. van der Zwaan, eds., Nuclear Energy: Promise or Peril?, World Scientific, UK/Singapore, 1999.

IAEA, Atomic Energy and the Environment, and Electricity, Nuclear Power and the Global Environment, IAEA Information Series, Vienna.

IAEA, Climate Change and Nuclear Power, Vienna, November 2000.

IAEA, Radiation, Health and Society, Vienna, 1997.

IAEA, The Potential Role for Nuclear Power in a Sustainable Energy Future, Report for CENRD - CSD-9, 2000.

IIASA/WEC, Global Energy Perspectives, Cambridge University Press, 1998, and http://www.iiasa.ac.at.

Houlder, V., 'Generating Action and Reaction', Financial Times, January 10, 2001.

IPCC, International Panel on Climate Change, Workgroup III, Third Assessment Report, 2001.

Levensduurverkorting Radioactief Afval, ECN, Petten, 1998.

May, M., 'Energy and Security in Asia', IIS, Stanford University, 1998.

OECD/IEA, Nuclear Power, Sustainability, Climate Change and Competition, Paris, 1998.

OECD/IEA/NEA, Business as Usual and Nuclear Power, Paris, 1999.

OECD/NEA, Nuclear Energy in a Sustainable Development Perspective, Paris, 2000.

Paffenberger, J.A. and E. Bertel, Results from the OECD report on International Projects of Electricity Generating Costs, paper presented at IJPGC 1998: International Joint Power Generation Conference and Exhibition, 24-26 August 1998.

The Pebble Bed Modular Reactor: Why small may be the future of nuclear, NUKEM, 7, July 2000.

Pew Center, 'Developing Countries and Global Climate Change', May 2000.

Radetzki, M., 'Coal or Nuclear in New Power Stations', Energy Journal 21, 1, 2000.

Royal Society, Nuclear energy - the future climate, The Royal Society and The Royal Academy of Engineering, London, 1999. 
Sailor, W. C., D. Bodansky, C. Braun, S. Fetter and B.C.C. van der Zwaan, A Nuclear Solution to Climate Change?, Science, Vol. 288, 19 May 2000, pp. 1177-1178.

Turkenburg, W.C., Kernenergie en Duurzame Ontwikkeling, Deelstudie 8 van Technology Assessment HTR, rapport ECN-C--96-048, juni 1996.

WCED, World Commission on Environment and Development (Brundtland Commission), Our Common Future, Oxford University Press, Oxford, 1987.

WRR, Sustained risks - A lasting phenomenon, SDU, The Hague, 1995.

Zwaan, B.C.C. van der, Energie Nucléaire dans le $21^{e}$ Siècle: Enjeux de Sécurité, Institut Français des Relations Internationales (IFRI, Paris, France), 1999.

Zwaan, B.C.C. van der, 'Nuclear Power and Global Warming', Survival, International Institute for Strategic Studies (London, UK), Vol. 42, no. 3, autumn 2000, pp. 61-71.

WEA, World Energy Assessment: Energy and the challenge of sustainability, 2001. 